\title{
Recurrent Supramolecular Motifs in a Series of Acid-Base Adducts Based on Pyridine-2,5-Dicarboxylic Acid N-Oxide and Organic Bases: Inter- and Intramolecular Hydrogen Bonding
}

\author{
Masoud Mirzaei,* Fereshteh Sadeghi, Krešimir Molčanov, Jan K. Zaręba,* Rosa M. Gomila, \\ and Antonio Frontera*
}

Cite This: Cryst. Growth Des. 2020, 20, 1738-1751

Read Online

\section{ACCESS |}

Џlll Metrics \& More

国 Article Recommendations

Supporting Information

ABSTRACT: Salts and ionic cocrystals simultaneously comprising $\mathrm{N}$-oxide and carboxylic acid functional groups constitute a very fertile ground for the investigation of various proton transfer phenomena. This is because such compounds combine two types of proton transfer: that is, inter- and intramolecular hydrogen bonding in acid-base systems. To this end, a series of novel salts based on pyridine-2,5-dicarboxylic acid $\mathrm{N}$-oxide $\left(\mathrm{H}_{2}\right.$ pydco $)$ as an organic acid and 2,4,6-triamino-1,3,5-triazine (tata), 2-aminopyrimidine (2a-pym), 2-amino-6-methylpyridine (2a-6mpy), 1,10phenanthroline (phen), and 9-aminoacridine (9a-acr) as organic

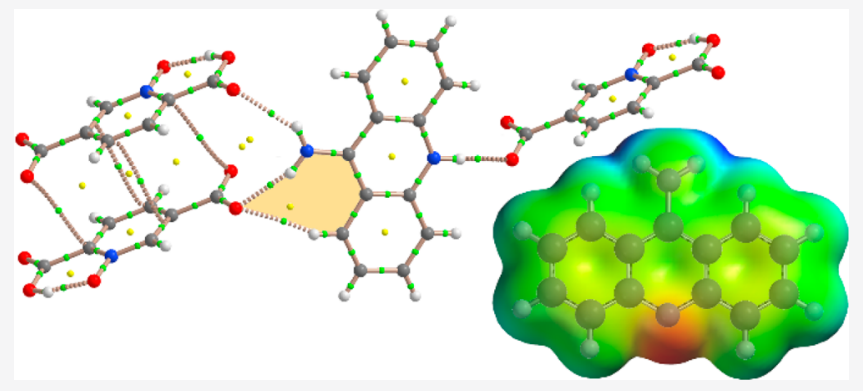
bases have been synthesized and characterized by elemental analyses, infrared spectroscopy, and single-crystal X-ray diffraction: $(\text { Htata })^{+}(\text {Hpydco })^{-}(1),(\mathrm{H} 2 \mathrm{a}-\mathrm{pym})^{+}(\mathrm{Hpydco})^{-}(2),(\mathrm{H} 2 \mathrm{a}-$ $6 \mathrm{mpy})^{+}(\mathrm{Hpydco})^{-}(\mathbf{3 A}, \mathbf{B}),\left[(\mathrm{Hphen})^{+}(\mathrm{Hpydco})^{-}\right]\left(\mathrm{H}_{2}\right.$ pydco $)(4)$, and $\left[(\mathrm{H} 9 \mathrm{a}-\mathrm{acr})^{+}(\mathrm{Hpydco})^{-}\right] \cdot$ EtOH (5). The unit cells of 3A and 3B differ slightly; however, $3 \mathbf{A}$ crystallizes in a chiral orthorhombic space group $P 2_{1} 2_{1} 2_{1}$, while $3 \mathbf{B}$ crystallizes in the achiral space group $P 2_{1} / n$. In both cases, the asymmetric unit comprises one cation and one anion. The influence of different organic cations on the packing of $\mathrm{Hpydco}^{-}$in the crystal lattice is studied. The most important feature of these crystals is the presence of extensive O$\mathrm{H} \cdots \mathrm{O}, \mathrm{N}-\mathrm{H} \cdots \mathrm{O}, \mathrm{N}-\mathrm{H} \cdots \mathrm{N}$, and $\mathrm{C}-\mathrm{H} \cdots \mathrm{O}$ hydrogen bond networks, which form base-dependent supramolecular synthons: 1, 2, and 3A,B comprise an $\alpha$-aminopyridinium moiety, and all involve the hydrogen-bonded motif $R_{2}^{2}(8)$ with the $\mathrm{Hpydco}^{-}$anion. Compounds 4 and 5, which lack the $\alpha$-aminopyridinium moiety, reveal different hydrogen-bonding patterns. The interaction energies of each individual hydrogen bond have been estimated using the quantum theory of "atoms-in-molecules", which led us to the identification of the energetically favorable antielectrostatic $\mathrm{N}-\mathrm{H} \cdots \mathrm{N}$ hydrogen bonds (stabilization energy of $4.0 \mathrm{kcal} / \mathrm{mol}$ ) between positively charged melaminium species in $\mathbf{1}$. It has been also established that charge-assisted hydrogen bonding does not always offer an energetic advantage over "noncharged" hydrogen bonds. With the use of Hirshfeld surface (HS) analysis we have also explored the influence of the protonation state of pydco species on the composition of contact contributions, as well as established specific properties of their 2D fingerprint plots. Finally, a comment is provided on the applicability of HS analysis for the exploration of polymorphs featuring intramolecular proton transfer.

\section{INTRODUCTION}

Crystalline solids are formed when molecules arrange in a very orderly fashion by means of many types of intermolecular interactions such as classical and nonclassical hydrogen bonding, halogen bonding, $\pi$ stacking, ion pairing, and van der Waals and donor-acceptor interactions, to name only a few. The importance of crystal engineering is highlighted when our purpose is to obtain a compound with desired solid-state properties, to understand the stability (or its lack) of a given crystalline network or structural motif, or to answer the question: "How do crystalline solids self-assemble?". For this purpose, one of the most leading and efficient methods is the use of single-crystal X-ray diffraction for experimental structure determination and confrontation of the obtained results with the knowledge already garnered by crystal engineers. ${ }^{1-4}$ In cases where different crystalline structures are obtained but feature the same composition (polymorphism phenomenon), crystallographic structural analysis is one of the most effective research methods that allow one to resolve the fine details of the molecular environment of such species. Generally, polymorphs have different properties such as melting point, stability, density, crystal habit, etc. Polymorphs are classified into several subcategories, such as conformation, packing, synthon, structural polymorphism, etc. Furthermore, poly-

Received: November 3, 2019

Revised: January 24, 2020

Published: February 5, 2020 
morphism is not limited to single-component crystal structures only; on the contrary, salts are a very fertile area for the formation of polymorphic structures. Indeed, a salt formation strategy can be used to develop drugs to enhance their physicochemical and clinical properties, such as solubility in water, dissolution rate, chemical stability, tableting, etc. At least half of the marketed active pharmaceutical ingredients (APIs) are administered as salts. In general, a salt is formed via proton transfer from an acid to a base, leading to the formation of a conjugate acid (protonated base) and conjugate base (deprotonated acid). ${ }^{5-7}$ Over the past decade, Mirzaei et al. have focused on the synthesis and structural characterization of novel supramolecular proton-transferred compounds ${ }^{8-13}$ and coordination complexes ${ }^{14,15}$ based on derivatives of pyridinedicarboxylic acids, owing to their remarkable applications such as anticancer properties, anti-HIV agent, gas adsorbent, etc. $^{16-23}$

In this paper, we report on the synthesis and X-ray characterization of a series of new salts with $\mathrm{N}$-containing organic aromatic bases such as 2,4,6-triamino-1,3,5-triazine (tata), 2-aminopyridimidine (2a-pym), 2,6-diaminopyridine (2a-6mpy), phenanthroline (phen), and 9-aminoacridine (9aacr) (Scheme 1) and pyridine-2,5-dicarboxylic acid $N$-oxide

Scheme 1. (Top) Structural Formula of $\mathrm{H}_{2}$ pydco and (Bottom) Structural Formulas and Abbreviations Used for Aromatic Bases

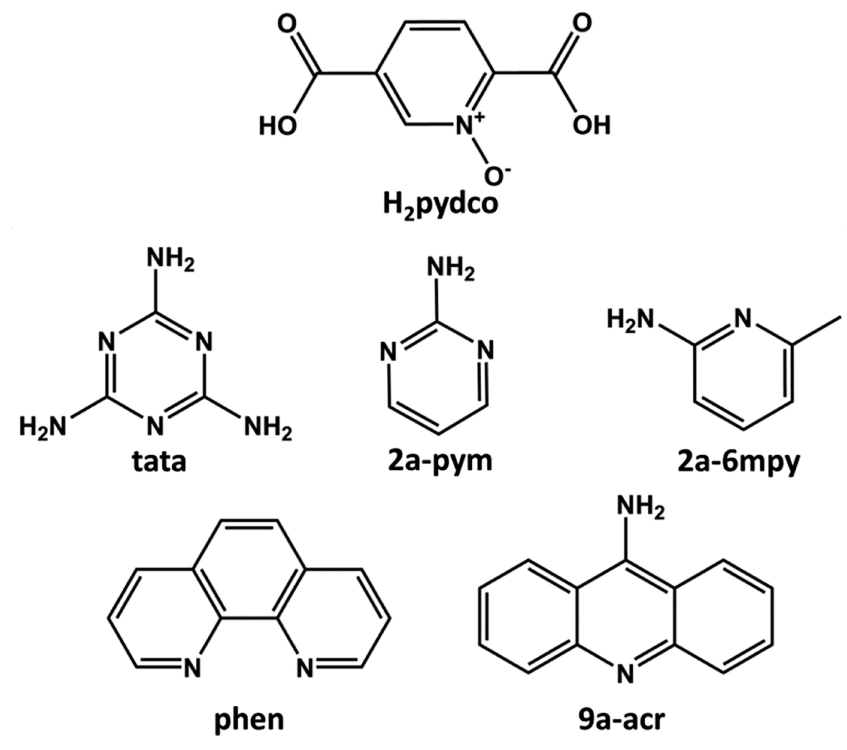

$\left(\mathrm{H}_{2}\right.$ pydco $)$ as the organic acid, using a proton transfer mechanism: $(\text { Htata })^{+}\left(\mathrm{Hpydco}^{-}(\mathbf{1}),(\mathrm{H} 2 \mathrm{a}-\mathrm{pym})^{+}\left(\mathrm{Hpydco}^{-}\right.\right.$ (2), (H2a-6mpy $)^{+}(\text {Hpydco })^{-}$(two polymorphs, $3 \mathbf{A}$ and $\left.3 \mathbf{B}\right)$, $\left[(\text { Hphen })^{+}(\text {Hpydco })^{-}\right]\left(\mathrm{H}_{2}\right.$ pydco $)(4)$, and $[(\mathrm{H} 9 \mathrm{a}-$ acr $\left.)^{+}(\text {Hpydco })^{-}\right] \cdot E t O H ~(5)$. It is generally accepted that, if there is an adequate $\mathrm{p} K_{\mathrm{a}}$ difference between the $\mathrm{COOH}$ of the aromatic acid and the nitrogen atom of the aromatic amine, a proton transfer phenomenon will occur and will likely generate the ionic hydrogen bond $\mathrm{N}^{+}-\mathrm{H} \cdots \mathrm{O}^{-22,23}$ Single crystals of salts $\mathbf{2}-\mathbf{5}$ were obtained in the presence of $\mathrm{Mn}$ (II) ion, but no coordination compounds have been isolated, probably due to the preferential formation of stable, extended networks of hydrogen bonds, supported by the process of proton transfer. $^{24,25}$ In that context it is worth adding that only four complexes with $\mathrm{H}_{2}$ pydco and lanthanoids were found in the
Cambridge Structural Database (CSD version 5.40 updates (November 2018)). ${ }^{26}$ Given the tendency of $\mathrm{H}_{2}$ pydco to participate in complex hydrogen-bonded networks, in this contribution, we decided to more closely explore the aforementioned acid-base adducts (five salts and one ionic cocrystal) involving $\mathrm{H}_{2}$ pydco and characterize their supramolecular behavior. We place a particular focus on the determination of recurrent supramolecular motifs that emerge from their intermolecular and intramolecular hydrogen bonding patterns. Insight into these properties is obtained with the use of classical structure description involving determination of hydrogen bond ring and chain motifs as well as Hirshfeld surface analysis. Experimental observations are corroborated by a DFT study, which offers the opportunity for evaluation of the energetic contribution of hydrogen bonds, which are formed between the counterions and also between the units of the same sign (cation $\cdots$ cation and anion $\cdots$ anion).

\section{METHODS}

General Methods and Materials. All chemicals and solvents used for the syntheses were of reagent grade and were purchased from Merck Chemicals and used without further purification. The organic acid $\left(\mathrm{H}_{2}\right.$ pydco $)$ was synthesized according to a reported procedure. ${ }^{15}$ Melting points were determined using a Barnstead Electrothermal 9300 apparatus. IR spectra were recorded from $\mathrm{KBr}$ pellets in the $4000-400 \mathrm{~cm}^{-1}$ region using a Buck 500 IR spectrometer. Elemental analysis (CHN) was performed using a Thermo Finnigan Flash1112EA microanalyzer.

Crystallographic Analyses. Single-crystal measurements were performed on an Oxford Diffraction Xcalibur Nova R (microfocus $\mathrm{Cu}$ tube) equipped with an Oxford Instruments CryoJet liquid nitrogen cooling device. The program package CrysAlis PRO (Agilent, 2011) ${ }^{27}$ was used for data reduction and numerical absorption correction. The structures were solved using SHELXS $97^{28}$ and refined with SHELXL$2017 .^{28}$ The models were refined using full-matrix least-squares refinement; all non-hydrogen atoms were refined anisotropically. Hydrogen atoms were located in a difference Fourier map and refined as either free entities or a mixture of free and riding entities. Water molecules were refined using the following restraints: $\mathrm{O}-\mathrm{H}$ bonds were restrained to $0.95(2) \AA$, and $\mathrm{H} \cdots \mathrm{H}$ distances were restrained to 1.50(4) Å.

Synthesis of (Htata) $)^{+}(\text {Hpydco })^{-}$(1). A solution of $\mathrm{H}_{2}$ pydco $(0.037 \mathrm{~g}, 0.20 \mathrm{mmol})$ in ethanol/water $(1 / 1 ; 10 \mathrm{~mL})$ was added dropwise to a solution of tata $(0.025 \mathrm{~g}, 0.20 \mathrm{mmol})$ in deionized water $(5 \mathrm{~mL})$ and stirred for $4 \mathrm{~h}$. After 1 week, colorless block-shaped crystals of 1 were obtained in about $47 \%$ yield (based on $\mathrm{H}_{2}$ pydco) by slow evaporation. $\left(\mathrm{mp}>300{ }^{\circ} \mathrm{C}\right)$. Anal. Calcd for $\mathrm{C}_{10} \mathrm{H}_{11} \mathrm{~N}_{7} \mathrm{O}_{5}$ : C, 38.84; H, 3.59; N, 31.71. Found: C, 39.81; H, 3.38; N, 32.05. IR ( $\mathrm{KBr}$ pellet, $\left.\mathrm{cm}^{-1}\right): 3427(\mathrm{~m}), \quad 3297(\mathrm{~m}), 1674(\mathrm{~s}), \quad 1645(\mathrm{~s}), \quad 1512(\mathrm{~m})$, 1372(s), 1228(w).

Synthesis of $(\mathrm{H} 2 \mathrm{a}-\mathrm{pym})^{+}(\mathrm{Hpydco})^{-}$(2). A solution of $\mathrm{H}_{2}$ pydco $(0.029 \mathrm{~g}, 0.16 \mathrm{mmol}), \mathrm{MnO}_{2}(0.007 \mathrm{~g}, 0.08 \mathrm{mmol})$, and $2 \mathrm{a}-\mathrm{pym}$ $(0.015 \mathrm{~g}, 0.16 \mathrm{mmol})$ in ethanol/water $(1 / 1 ; 25 \mathrm{~mL})$ was prepared and stirred for $4 \mathrm{~h}$ under mild conditions. After 10 days colorless prism-shaped diffraction-quality single crystals of $\mathbf{2}$ were obtained and collected through a slow evaporation of the solvent under ambient conditions in about $57 \%$ yield (based on $\mathrm{H}_{2}$ pydco) (mp $205{ }^{\circ} \mathrm{C}$ ). Anal. Calcd for $\mathrm{C}_{11} \mathrm{H}_{10} \mathrm{~N}_{4} \mathrm{O}_{5}$ : C, 47.49; H, 3.62; N, 20.14. Found: $\mathrm{C}$, 48.73; H, 3.28; N, 21.38. IR (KBr pellet, $\mathrm{cm}^{-1}$ ): 3292(br), 2704(w), 1972(m), 1707(s), 1679(s), 1552(m), 1370(s), 1263(m), 1228(w).

Synthesis of $(\mathrm{H} 2 \mathrm{a}-6 \mathrm{mpy})^{+}(\mathrm{Hpydco})^{-}(3 \mathrm{~A})$. A solution of $\mathrm{H}_{2}$ pydco $(0.029 \mathrm{~g}, 0.16 \mathrm{mmol}), \mathrm{MnCl}_{2} \cdot 2 \mathrm{H}_{2} \mathrm{O}$ (0.013 g, 0.08 $\mathrm{mmol})$, and $2 \mathrm{a}-6 \mathrm{mpy}(0.017 \mathrm{~g}, 0.16 \mathrm{mmol})$ in ethanol/water $(3 / 1$; $40 \mathrm{~mL}$ ) was prepared and stirred for $4 \mathrm{~h}$ under mild conditions. After 15 days yellow prism-shaped diffraction-quality single crystals of $3 \mathrm{~A}$ were obtained and collected through a slow evaporation of the solvent under ambient conditions in about $45 \%$ yield (based on $\mathrm{H}_{2}$ pydco) (mp $185{ }^{\circ} \mathrm{C}$ ). Anal. Calcd for $\mathrm{C}_{13} \mathrm{H}_{13} \mathrm{~N}_{3} \mathrm{O}_{5}$ : C, 53.61; H, 4.50; N, 
Table 1. Crystal Data and Data Collection and Refinement Parameters for 1-5

\begin{tabular}{|c|c|c|c|c|c|c|}
\hline & 1 & 2 & $3 \mathbf{A}$ & $3 B$ & 4 & 5 \\
\hline \multicolumn{7}{|c|}{ Crystal Data and Data Collection Parameters } \\
\hline empirical formula & $\mathrm{C}_{10} \mathrm{H}_{11} \mathrm{~N}_{7} \mathrm{O}_{5}$ & $\mathrm{C}_{11} \mathrm{H}_{10} \mathrm{~N}_{4} \mathrm{O}_{5}$ & $\mathrm{C}_{13} \mathrm{H}_{13} \mathrm{~N}_{3} \mathrm{O}_{5}$ & $\mathrm{C}_{13} \mathrm{H}_{13} \mathrm{~N}_{3} \mathrm{O}_{5}$ & $\mathrm{C}_{26} \mathrm{H}_{18} \mathrm{~N}_{4} \mathrm{O}_{10}$ & $\mathrm{C}_{22} \mathrm{H}_{21} \mathrm{~N}_{3} \mathrm{O}_{6}$ \\
\hline formula wt & 309.26 & 278.23 & 1165.06 & 291.26 & 546.44 & 399.36 \\
\hline cryst syst & triclinic & monoclinic & orthorhombic & monoclinic & triclinic & triclinic \\
\hline space group & $P \overline{1}$ & $P 2_{1} / n$ & $P 2_{1} 2_{1} 2_{1}$ & $P 2_{1} / n$ & $P \overline{1}$ & $P \overline{1}$ \\
\hline$a(\AA)$ & $8.2019(4)$ & $3.7453(1)$ & $6.6681(1)$ & $7.9463(2)$ & $6.9340(2)$ & $7.2141(6)$ \\
\hline$b(\AA)$ & $8.7490(6)$ & $10.8274(3)$ & $7.9560(1)$ & $6.6606(1)$ & $7.2620(3)$ & $11.1551(6)$ \\
\hline$c(\AA)$ & $10.0972(6)$ & $28.1248(8)$ & $25.7764(4)$ & $25.8445(5)$ & $23.590(8)$ & $13.2745(10)$ \\
\hline$\alpha(\mathrm{deg})$ & $95.149(5)$ & 90 & 90 & 90 & $85.019(3)$ & $69.808(7)$ \\
\hline$\beta(\operatorname{deg})$ & $109.230(5)$ & $90.814(3)$ & 90 & $93.909(2)$ & $87.751(3)$ & $89.600(7)$ \\
\hline$\gamma(\operatorname{deg})$ & $114.764(6)$ & 90 & 90 & 90 & $75.820(3)$ & $75.762(7)$ \\
\hline$V\left(\AA^{3}\right)$ & $598.91(6)$ & $1140.40(5)$ & $1367.47(3)$ & $1364.69(5)$ & $1147.17(7)$ & $968.23(12)$ \\
\hline$Z$ & 2 & 4 & 1 & 4 & 2 & 2 \\
\hline$\mu\left(\mathrm{mm}^{-1}\right)$ & 1.22 & 1.13 & 0.94 & 0.94 & 1.06 & 0.87 \\
\hline $\begin{array}{l}\text { no. of measd, indep, and obsd indices } \\
\quad(I>2 \sigma(I)) \text { rflns }\end{array}$ & $\begin{array}{l}6407,2262 \\
1849\end{array}$ & $\begin{array}{l}5014,2123 \\
1922\end{array}$ & $\begin{array}{l}6662,2721 \\
2587\end{array}$ & $\begin{array}{l}11674,2807 \\
2584\end{array}$ & $\begin{array}{l}10319,4698 \\
4195\end{array}$ & $\begin{array}{l}8494,3958 \\
3210\end{array}$ \\
\hline$R_{\text {int }}$ & 0.046 & 0.022 & 0.026 & 0.036 & 0.029 & 0.022 \\
\hline$(\sin \theta / \lambda)_{\max }\left(\AA^{-1}\right)$ & 0.618 & 0.628 & 0.628 & 0.629 & 0.629 & 0.630 \\
\hline \multicolumn{7}{|c|}{ Refinement Parameters } \\
\hline$R\left(F^{2}>2 \sigma\left(F^{2}\right)\right), R_{\mathrm{w}}\left(F^{2}\right), S$ & $\begin{array}{l}0.051,0.160 \\
1.04\end{array}$ & $\begin{array}{l}0.051,0.155 \\
\quad 1.11\end{array}$ & $\begin{array}{l}0.038,0.109 \\
1.04\end{array}$ & $\begin{array}{l}0.046,0.141 \\
1.09\end{array}$ & $\begin{array}{l}0.045,0.134 \\
\quad 1.05\end{array}$ & $\begin{array}{l}0.073,0.246 \\
\quad 1.04\end{array}$ \\
\hline no. of rflns & 2262 & 2123 & 2721 & 2807 & 4698 & 3958 \\
\hline no. of params & 207 & 190 & 190 & 194 & 362 & 286 \\
\hline no. of restraints & 0 & 0 & 0 & 0 & 0 & 30 \\
\hline$\Delta \rho_{\max } \Delta \rho_{\min }\left(\mathrm{e} \AA^{-3}\right)$ & $0.31,-0.42$ & $0.24,-0.16$ & $0.17,-0.18$ & $0.21,-0.19$ & $0.29,-0.19$ & $0.73,-0.28$ \\
\hline
\end{tabular}

14.43. Found: C, 54.47; H, 4.23; N, 14.65. IR (KBr pellet, $\left.\mathrm{cm}^{-1}\right)$ : 3292(m), 2798(w), 1981(m), 1695(m), 1498(w), 1365(s), 1249(m).

Synthesis of $(\mathrm{H} 2 \mathrm{a}-6 \mathrm{mpy})^{+}(\mathrm{Hpydco})^{-}$(3B). A solution of $\mathrm{H}_{2}$ pydco $(0.029 \mathrm{~g}, 0.16 \mathrm{mmol}), \mathrm{MnCl}_{2} \cdot 2 \mathrm{H}_{2} \mathrm{O}$ (0.026 g, 0.16 $\mathrm{mmol})$, and 2a-6mpy $(0.034 \mathrm{~g}, 0.32 \mathrm{mmol})$ in ethanol $(10 \mathrm{~mL})$ was prepared and stirred for $4 \mathrm{~h}$ under mild conditions. After 10 days colorless prism-shaped diffraction-quality single crystals of 3B were obtained and collected through a slow evaporation of the solvent under ambient conditions in about $60 \%$ yield (based on $\mathrm{H}_{2}$ pydco) (mp $199{ }^{\circ} \mathrm{C}$ ). Anal. Calcd for $\mathrm{C}_{13} \mathrm{H}_{13} \mathrm{~N}_{3} \mathrm{O}_{5}$ : C, 53.61; H, 4.50; N, 14.43. Found: C, 54.51; H, 4.12; N, 14.60. IR ( $\mathrm{KBr}$ pellet, $\left.\mathrm{cm}^{-1}\right)$ : 3283(br), 1971(m), 1693(s), 1635(m), 1585(m), 1379(s), 1252(m), 1223(w).

Synthesis of $\left[(\text { Hphen })^{+}\left(\mathrm{Hpydco}^{-}\right] \cdot\left(\mathrm{H}_{2}\right.\right.$ pydco) (4). A solution of $\mathrm{H}_{2}$ pydco $(0.037 \mathrm{~g}, 0.20 \mathrm{mmol}), \mathrm{MnCl}_{2} \cdot 2 \mathrm{H}_{2} \mathrm{O}$ (0.032 g, 0.20 $\mathrm{mmol})$, and 1,10-phenanthroline hydrate $(0.040 \mathrm{~g}, 0.20 \mathrm{mmol})$ in ethanol/water $(1 / 1 ; 25 \mathrm{~mL})$ was prepared and stirred for $4 \mathrm{~h}$ under mild conditions. After 20 days colorless prism-shaped diffractionquality single crystals of $\mathbf{5}$ were obtained and collected through a slow evaporation of the solvent under ambient conditions in about $47 \%$ yield (based on $\mathrm{H}_{2}$ pydco) ( $\mathrm{mp} 200{ }^{\circ} \mathrm{C}$ ). Anal. Calcd for $\mathrm{C}_{26} \mathrm{H}_{18} \mathrm{~N}_{4} \mathrm{O}_{10}$ : C, 57.15; H, 3.32; N, 10.25. Found: C, 57.33; H, 3.15; N, 10.38. IR ( $\mathrm{KBr}$ pellet, $\left.\mathrm{cm}^{-1}\right): 3446(\mathrm{br}), 3076(\mathrm{~m}), 1678(\mathrm{~s})$, 1537(m), 1393(s), 1245(m).

2.8. Synthesis of $\left[(\mathrm{H9a}-\mathrm{acr})^{+}(\mathrm{Hpydco})^{-}\right] \cdot \mathrm{EtOH}(5)$. A solution of $\mathrm{H}_{2}$ pydco $(0.37 \mathrm{~g}, 0.20 \mathrm{mmol}), \mathrm{MnCl}_{2} \cdot 2 \mathrm{H}_{2} \mathrm{O}(0.016 \mathrm{~g}, 0.10 \mathrm{mmol})$, and $9 \mathrm{a}$-acr $(0.019 \mathrm{~g}, 0.10 \mathrm{mmol})$ in ethanol/water $(1 / 1 ; 30 \mathrm{~mL})$ was prepared and stirred for $8 \mathrm{~h}$ under mild conditions. Yellow needleshaped crystals were obtained after 2 weeks in about $61 \%$ yield (based on $\mathrm{H}_{2}$ pydco) by slow evaporation (mp $244{ }^{\circ} \mathrm{C}$ ). Anal. Calcd for $\mathrm{C}_{22} \mathrm{H}_{21} \mathrm{~N}_{3} \mathrm{O}_{6}$ : C, 62.41; H, 5.00; N, 9.92. Found: C, 63.05; H, 4.70; N, 10.86. IR (KBr pellet, $\left.\mathrm{cm}^{-1}\right)$ : 3456(br), 3172(m), 1742(m), 1655(s), 1615(s), 1548(w), 1407(m), 1263(m), 1225(w).

Theoretical Methods. All DFT calculations were carried out using the Gaussian-16 program ${ }^{29}$ at the B3LYP-D3/def2-TZVP level of theory and using the crystallographic coordinates (only the positions of the $\mathrm{H}$ atoms have been optimized). Atoms in molecules $(\mathrm{AIM})^{30}$ analysis was performed at the same level of theory. The calculation of AIM properties was done using the AIMAll program. ${ }^{31}$

\section{RESULTS AND DISCUSSION}

Infrared Spectroscopy. The IR spectra of $\mathrm{H}_{2}$ pydco and all studied compounds are shown in Figure $\mathrm{S} 1$ in the Supporting Information. The absorptions at 3000-3500 $\mathrm{cm}^{-1}$ can be assigned to the $\mathrm{NH}$ and $\mathrm{OH}$ stretching vibrations of the amino groups or $\mathrm{O}-\mathrm{H}$ in the carboxylate group of the $\mathrm{H}_{2}$ pydco ligand and water molecules, respectively. ${ }^{32,33}$ The strong band $\nu_{\text {as }}\left(\mathrm{COO}^{-}\right)$and $\nu_{\mathrm{s}}\left(\mathrm{COO}^{-}\right)$stretching modes appeared for free $\mathrm{H}_{2}$ pydco at 1726 and $1419 \mathrm{~cm}^{-1}$, respectively, which were shifted in all of the compounds to lower wavenumbers in the ranges 1695-1626 and 1407-1365 $\mathrm{cm}^{-1}$, respectively. Furthermore, in the infrared spectrum of $\mathrm{H}_{2}$ pydco (Figure $\mathrm{S} 1$ ) a strong band at $1230 \mathrm{~cm}^{-1}$ can be attributed to the presence of an $\mathrm{N}-\mathrm{O}$ group. ${ }^{26}$ Bands in the $1228-1207 \mathrm{~cm}^{-1}$ region for all compounds were assigned to the stretching vibration of the $\mathrm{N}-\mathrm{O}$ group.

Description of the Crystal Structures. The crystallographic and collection data for $\mathbf{1 - 5}$ are gathered in Table 1 . Additionally, selected bond lengths, valence angles, and hydrogen bond geometries are given in Tables S1 and S2 in the Supporting Information. In all studied salts the Hpydco ${ }^{-}$ anion forms an intramolecular hydrogen bond between a carboxyl moiety and the $N$-oxide group, which can be represented by an $S_{1}{ }^{1}(6)$ graph set ${ }^{34,35}$ (Figure 1a). The hydrogen bond is stabilized by resonance (RAHB) of the carboxyl and $\mathrm{N}-\mathrm{O}$ groups.

Compounds 1, 2, and 3A,B contain an $\alpha$-aminopyridinium moiety, and all form the hydrogen-bonded motif $R_{2}^{2}(8)$ with the $\mathrm{Hpydco}^{-}$anion (Figure 1b). An attraction of proton donors and acceptors is augmented here by the negative charge of the carboxylate group of the $\mathrm{Hpydco}^{-}$anion; thus, a pair of resonance- and charge-assisted hydrogen bonds (CAHB, RAHB) is formed. This fragment is a well-known supramolecular synthon. ${ }^{35} 3 \mathrm{D}$ packings of compounds $\mathbf{1}, \mathbf{2}, \mathbf{3 A}, \mathbf{B}$ are 


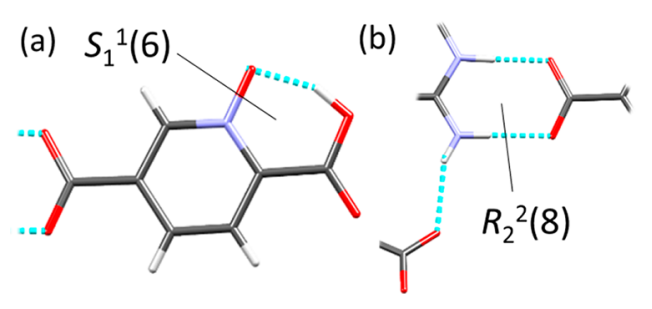

Figure 1. Highly conserved hydrogen bonded motifs: (a) an $S_{1}{ }^{1}(6)$ ring present in all $\mathrm{Hpydco}^{-}$anions and (b) an $R_{2}{ }^{2}(8)$ ring present in 1,2 , and 3A,B.

completed by other proton donors and acceptors forming secondary hydrogen-bonded motifs. Compounds 4 and 5, which lack the $\alpha$-aminopyridinium moiety, form different hydrogen-bonding patterns.

Crystal Structure of $(\text { Htata })^{+}\left(\right.$Hpydco $^{-}$(1). The asymmetric unit 1 consists of one cation (Htata) ${ }^{+}$and one anion (Hpydco $)^{-}$(see Figure 2). The intramolecular hydrogen bond in the $S_{1}{ }^{1}(6)$ ring is particularly strong (the $\mathrm{H} 2 \cdots \mathrm{O} 3$ distance is $1.29(4) \AA)$. The cation and anion are bonded into one-dimensional (1D) infinite chains through five distinct $\mathrm{N}-$ $\mathrm{H} \cdots \mathrm{O}$ intermolecular hydrogen bonds. Within these chains one can identify four supramolecular synthons ${ }^{35}$ of $R_{2}^{2}(8), R_{2}^{2}(6)$, $R_{1}^{2}(4), R_{2}^{1}(4)$, graph set notations (Figure 3). The latter two motifs are components of larger $R_{2}^{2}(6)$ graph set. It is obvious that $\mathrm{O} 2$ and $\mathrm{H} 6 \mathrm{~B}$ atoms act as a double acceptor and a bifurcated donor, respectively.

Neighboring chains are linked to each other by $\mathrm{N}-\mathrm{H} \cdots \mathrm{O}$ and $\mathrm{N}-\mathrm{H} \cdots \mathrm{N}$ hydrogen bonds between the anions and cations, generating two-dimensional (2D) HB sheets. We recognize several cyclic synthons in this layer described by $R_{4}^{2}(8)$, $R_{2}{ }^{2}(8), R_{3}{ }^{2}(8)$, and $R_{4}{ }^{4}(26)$ graph sets (Figure $S 2$ in the Supporting Information). The three-dimensional (3D) network is built by several weak, but distinct, interactions: (i) $\pi$ interactions between anionic parts $\left(\mathrm{Hpydco}^{-}\right)$(3.484 $\AA$ ), (ii) $\pi$ interactions between cationic parts $\left(\mathrm{Htata}^{+}\right)(3.992 \AA)$, (iii) $\mathrm{C}-\mathrm{O} \cdots \pi$ interactions between oxygen of the 5-carboxylate group from $\mathrm{Hpydco}^{-}$and the triazine ring of $\mathrm{Htata}^{+}$(3.112 $\mathrm{A}$ ), and (iv) $\mathrm{N}-\mathrm{H} \cdots \pi$ interactions between nitrogen of the amino group from $\mathrm{Htata}^{+}$and the pyridine ring of $\mathrm{Hpydco}^{-}(3.627 \AA)$ (Figure S3 in the Supporting Information)..$^{1,36,37}$

Crystal Structure of $(\mathrm{H} 2 \mathrm{a}-\mathrm{pym})^{+}\left(\mathrm{Hpydco}^{-}\right.$(2). The asymmetric unit of $\mathbf{2}$ comprises one cation (H2a-pym) $)^{+}$and one anion $(\text { Hpydco })^{-}$(Figure 2). Each anion and cation forms a $\mathrm{R}_{2}{ }^{2}(8)$ dimer via strong $\mathrm{N}-\mathrm{H} \cdots \mathrm{O}$ hydrogen bonds, and then a $1 \mathrm{D}$ linear chain is created by $\mathrm{N}-\mathrm{H} \cdots \mathrm{O}$ (from the amino group, linking to another dimer) and $\mathrm{C}-\mathrm{H} \cdots \mathrm{O}$ hydrogenbonding interactions along the $b$ axis (Figure 4).

A 2D hydrogen-bonded network is created by connection of the linear chains along the $b$ axis through $\mathrm{N}-\mathrm{H} \cdots \mathrm{O}, \mathrm{C}-\mathrm{H} \cdots \mathrm{O}$, and $\mathrm{C}-\mathrm{H} \cdots \mathrm{N}$ hydrogen-bonding interactions along the side view (Figure 5). On the other hand, a linear chain along the $b$ axis creates another $2 \mathrm{D}$ supramolecular layer via $\pi$ stacking (with a centroid $\cdots$ centroid separation of $3.745 \AA$ ) between pyridyl rings of anion fragments and $\pi$ stacking (with a centroid $\cdots$ centroid separation of $3.745 \AA$ ) between pyrimidyl rings of cation fragments along the $a b$ plane (Figure S4 in the Supporting Information).

Crystal Structures of Polymorphs (H2a$6 \mathrm{mpy})^{+}\left(\mathrm{Hpydco}^{-}(3 \mathrm{~A}, \mathrm{~B})\right.$. Two polymorphs of (H2a$6 \mathrm{mpy})^{+}(\mathrm{Hpydco})^{-}$were obtained, through modification of the solvent system combined with a change in the ratio of the reactants. Their unit cell parameters differ slightly (Table 1); however, 3A crystallizes in the chiral orthorhombic space group $P 2_{1} 2_{1} 2_{1}$, while $3 \mathrm{~B}$ crystallizes in the achiral space group $P 2_{1} / n$. In both cases the asymmetric unit comprises one cation and one anion.

In both crystal packings structural dimeric motifs of the $R_{2}{ }^{2}(8)$ notation are present. In $3 \mathbf{A}$ they are connected by the additional hydrogen bond $\mathrm{N}-\mathrm{H} \cdots \mathrm{O}$ into 1D linear chains along the a direction (Figure 6). These linear chains are connected to each other by $\pi$ stacking (with a centroid $\cdots$ centroid separation of $3.796 \AA$ ) between pyridyl rings of anion and cation fragments and thus form 2D layers (Figure 7). Along the $c$ axis a $1 \mathrm{D}$ ladder is created by $\mathrm{N}-\mathrm{H} \cdots \mathrm{O}$ hydrogen bonds and $\mathrm{C}-\mathrm{H} \cdots \mathrm{O}(\mathrm{H} 4 \cdots \mathrm{O} 32.58 \AA$ and $\mathrm{H} 9 \cdots \mathrm{O} 22.54 \AA$ ) interactions between the anion and cation in the crystal lattice (Figure 8). In 3B there are additional motifs formed by N$\mathrm{H} \cdots \mathrm{O}$ hydrogen bonds: namely, $\mathrm{C}_{2}{ }^{1}(4)$ and $\mathrm{C}_{2}{ }^{2}(8)$ (Figure 9). In 3B, anionic (Hpydco $)^{-}$, and cationic (H2a-6mpy) ${ }^{+}$ components of the structure are interdigitating and hold together through $(\mathrm{H} 10 \cdots \mathrm{O} 2 ; 2.50 \AA)$ interaction. As a result, 1D H-bonded chains are formed (Figure S5 in the Supporting Information). Finally, the linear chains are connected to each other by $\pi$ stacking (with a centroid...centroid separation of $3.796 \AA$ ) between pyridyl rings of anion and cation segments and thus form 2D layers (Figure S6 in the Supporting Information).

Crystal Structure of $\left[\left(\mathrm{Hphen}^{+}\left(\mathrm{Hpydco}^{-}\right]\right) \cdot\left(\mathrm{H}_{2}\right.\right.$ pydco $)$ (4). Compound 4 is an ionic cocrystal whose asymmetric unit includes one (Hphen $)^{+}$cation, one (Hpydco) ${ }^{-}$anion, and one neutral $\mathrm{H}_{2}$ pydco (Figure 10). In the main features of the crystal packing one can include hydrogen-bonded double chains parallel to the $b$ axis (Figure 10). These chains consist of alternating cationic and anionic components through

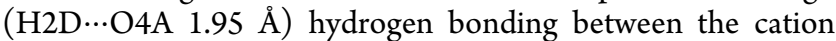
(N-H group) and anion (carboxylate group). There are also $\pi$ interactions (with a centroid...centroid separation of $3.507 \AA$ ) between the pyridyl ring of the anion and the phenyl ring of the cation.

Another column is created by neutral $\mathrm{H}_{2}$ pydco, which is linked to the former via $\mathrm{O}-\mathrm{H} \cdots \mathrm{O}$ and $\mathrm{C}-\mathrm{H} \cdots \mathrm{O}$ hydrogen bonds between two anionic and neutral components (Figure 10). The structure of salt 4 is repeated through anionic, neutral, and cationic portions and constructs a $1 \mathrm{D}$ linear chain along the side view via strong $\mathrm{O}-\mathrm{H} \cdots \mathrm{O}$ interactions between $\mathrm{H}_{2}$ pydco and $\mathrm{Hpydco}^{-}$and $\mathrm{C}-\mathrm{H} \cdots \mathrm{O}$ interactions of the pyridyl rings of $\mathrm{Hphen}^{+}$and oxygen atoms of $\mathrm{H}_{2}$ pydco and $\mathrm{Hpydco}^{-}$(Figure S7 in the Supporting Information). The linear chains (Figures S7 and S8 in the Supporting Information) are linked into $2 \mathrm{D}$ layers through of $\mathrm{C}-\mathrm{O} \cdots \pi$ (a C7AO3A $\cdots$ centroid separation of $3.654 \AA$ ) and $\pi$ interactions (with four different types of centroid $\cdots$ centroid separations of $3.617,3.661,3.507$, and $3.947 \AA$ ) between two rings of $\mathrm{Hphen}^{+}$and $\mathrm{Hpydco}^{-}$and $\mathrm{N}-\mathrm{O} \cdots \pi$ (an N1O5 $\cdots$ centroid separation of $3.766 \AA$ ) s $^{38}$ and $\pi$ interactions (with centroid $\cdots$ centroid separations of $3.794 \AA$ ) between pyridyl rings of the $\mathrm{H}_{2}$ phen neutral molecule along the $a$ axis.

Crystal Structure of $\left[(\mathrm{H9a}-\mathrm{acr})^{+}\left(\mathrm{Hpydco}^{-}\right] \cdot \mathrm{EtOH}\right.$ (5). Single-crystal X-ray diffraction analysis reveals that 5 crystallizes in space group $P \overline{1}$ of the triclinic crystal system. The asymmetric unit contains one $(\mathrm{H} 9 \mathrm{a}-\mathrm{acr})^{+}$cation, one (Hpydco) ${ }^{-}$anion, and one ethanol molecule (Figure 2). Two parallel 1D chains are generated with alternating cationic and anionic components through various $\mathrm{N}-\mathrm{H} \cdots \mathrm{O}$ hydrogen 

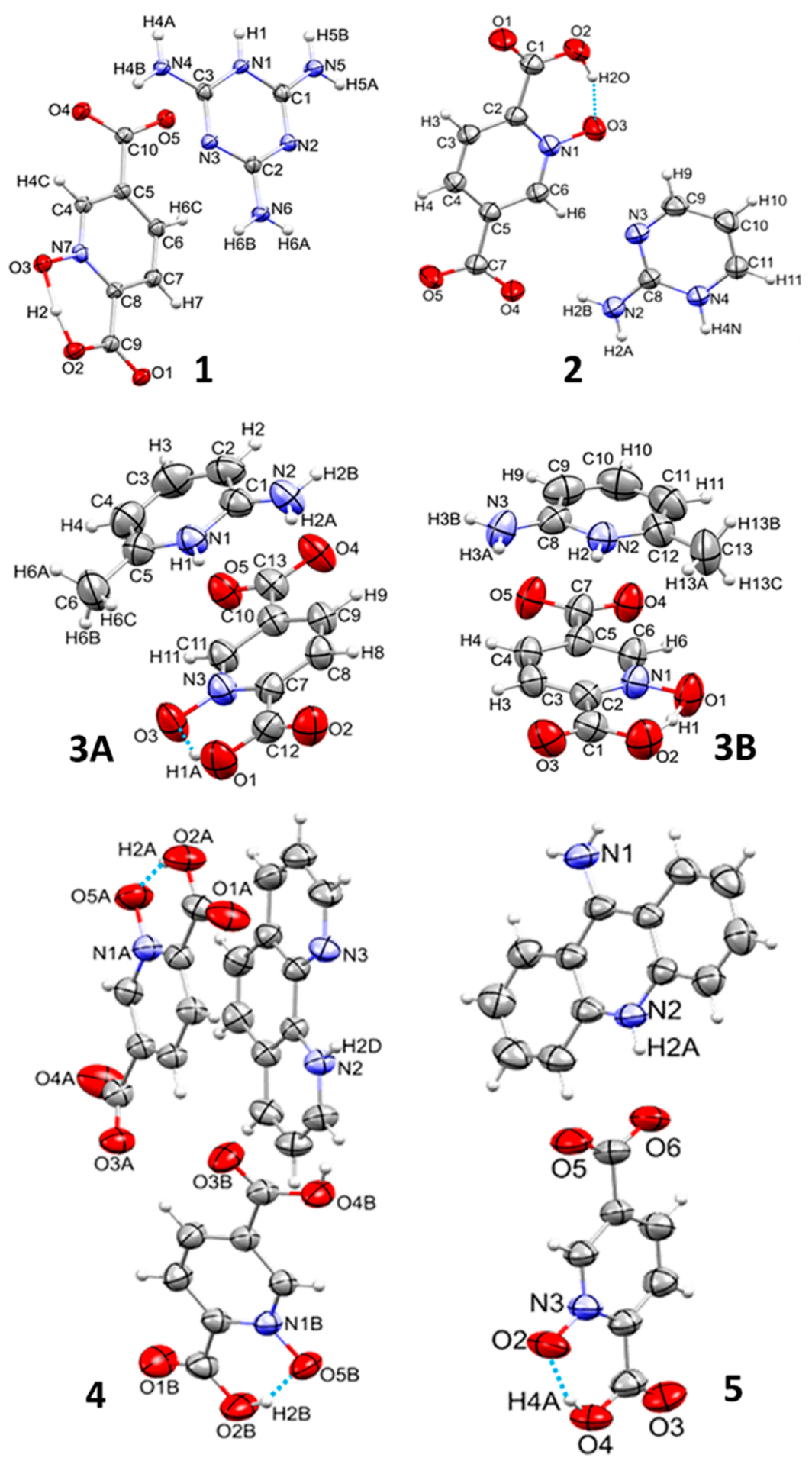

Figure 2. Molecular structures of compounds 1-5 with the displacement ellipsoids drawn at the 50\% probability level.

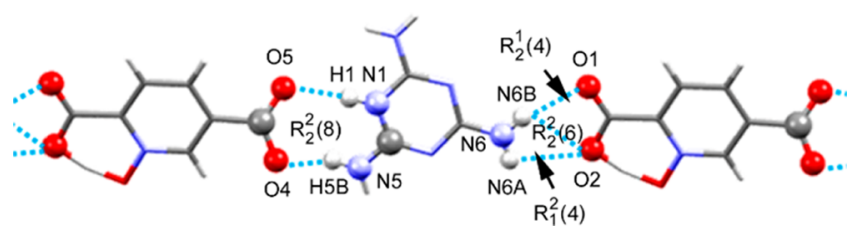

Figure 3. Schematic representation of cyclic motifs created by $\mathrm{N}-\mathrm{H} \cdots$ $\mathrm{O}$ hydrogen bonding in compound $\mathbf{1}$. bonds between cations ( $\mathrm{NH}$ and $\mathrm{NH}_{2}$ groups) and anions $\left(\mathrm{COO}^{-}\right.$and $\mathrm{COOH}$ groups) as well as $\mathrm{C}-\mathrm{H} \cdots \mathrm{O}(\mathrm{H} 2 \cdots \mathrm{O} 4$

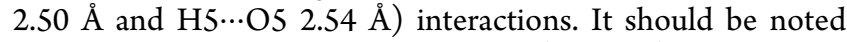
that all the aromatic rings from the $(\mathrm{H} 9 \mathrm{a}-\mathrm{acr})^{+}$cation and $(\text { Hpydco })^{-}$anion feature an antiparallel orientation (see Figure 11).

Adjacent acridinium rings are linked together via $\pi$ interactions (with two different types of centroid...centroid separations of 3.660 and $3.710 \AA$ ) in an $A B$ arrangement, and the pyridyl ring of (Hpydco) ${ }^{-}$participates in $\pi$-stacking (with centroid $\cdots$ centroid separation of $3.680 \AA$ ) interactions. More- 


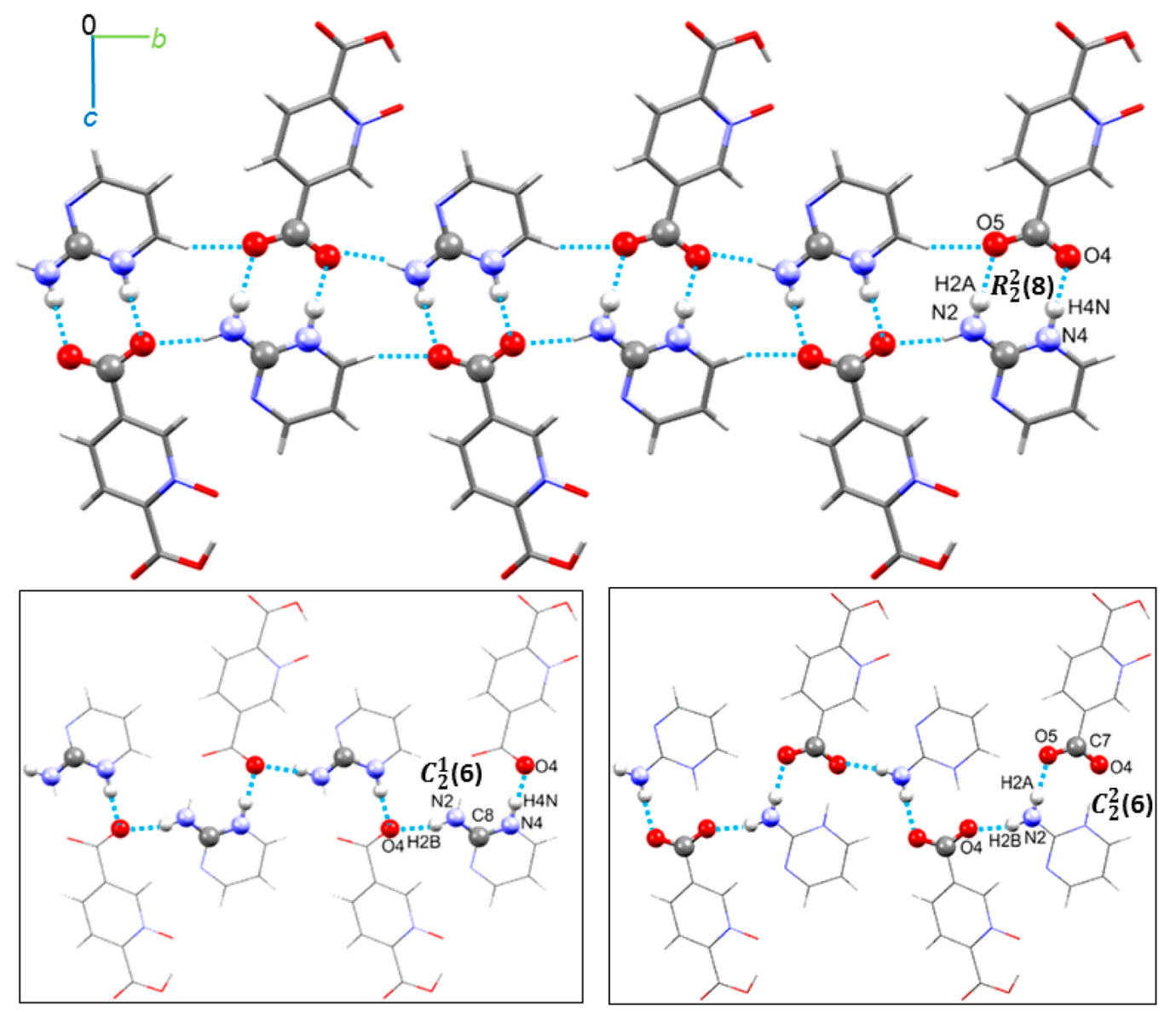

Figure 4. Schematic representation of the $1 \mathrm{D}$ linear chain along the $b$ axis by $\mathrm{N}-\mathrm{H} \cdots \mathrm{O}$ and $\mathrm{C}-\mathrm{H} \cdots \mathrm{O}$ hydrogen bonding and some graph set notations of 2 .

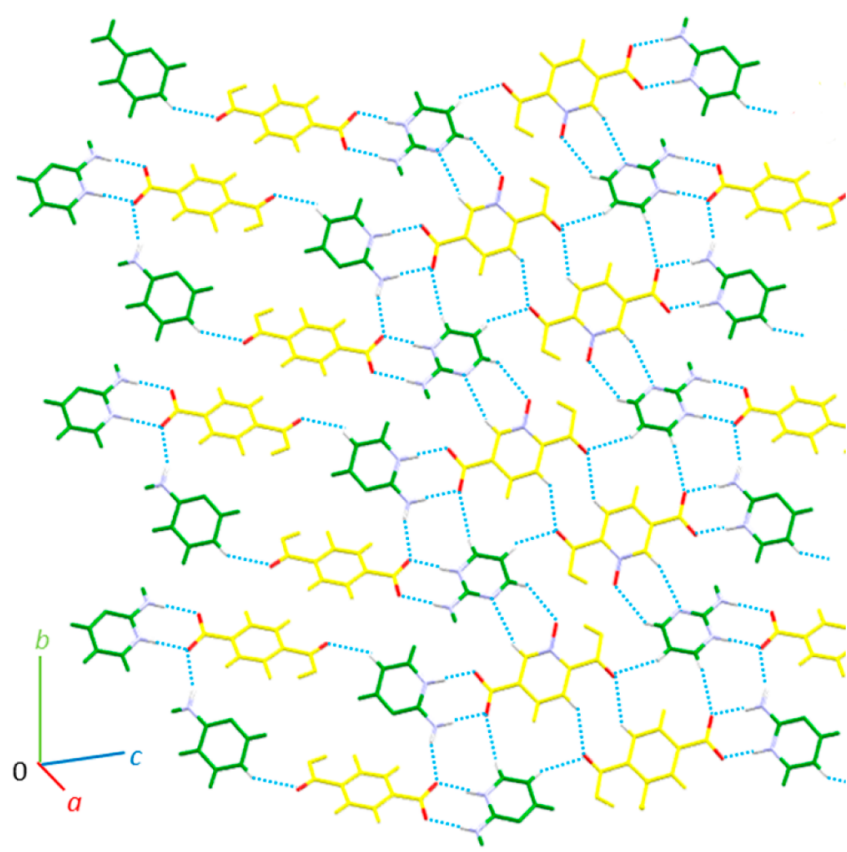

Figure 5. View of the 2D hydrogen-bonded coordination network formed by various hydrogen bonds in $\mathbf{2}$ along the side view. Symmetry-independent ions are shown in different colors (green and yellow).

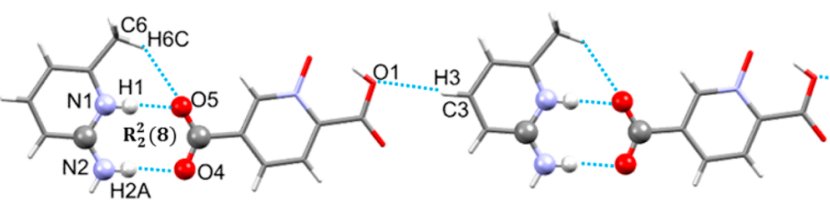

Figure 6. Perspective view of the $1 \mathrm{D}$ linear chain and cyclic graph-set notation in $\mathbf{3 A}$ along the $a$ direction.

over, in these chains $\mathrm{N}-\mathrm{H} \cdots \mathrm{O}$ hydrogen bonding creates the motifs $C_{2}{ }^{2}(8), R_{4}{ }^{4}(20)$, and $R_{4}{ }^{4}(22)$ (Figure 11). Additionally, these double chains are connected into $2 \mathrm{D}$ layers through

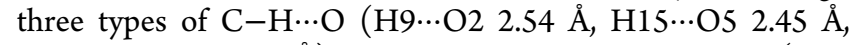
and $\mathrm{H} 18 \cdots \mathrm{O} 32.57 \AA$ ) interactions and $\pi$ interactions (with two different types of centroid...centroid separations of 3.799 and $3.915 \AA$ ) between all rings of the acridinium cation so that they interact with each other via an $\mathrm{ABA}$ arrangement, forming columns along the $a$ direction (Figure 12). ${ }^{39,40}$

Theoretical Study of Noncovalent Interactions. In order to confirm the existence and measure the strength of the H-bonding contacts described above, we carried out DFT calculations and carried out topological analysis of the electron density distribution within the framework of the quantum theory of atoms in molecules (QTAIM method). We have analyzed the supramolecular assemblies of compounds 1-5 and evaluated the contribution of each contact. We and others have successfully used this approach to analyze several types of noncovalent interactions. ${ }^{41}$ We have defined energies for the 


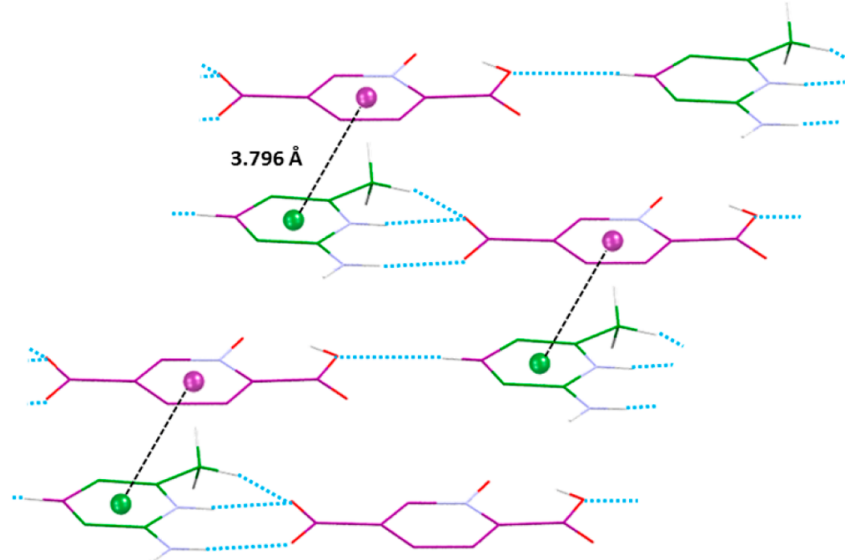

Figure 7. Representation of the $2 \mathrm{D}$ layer along the side view of $3 \mathrm{~A}$ formed via $\mathrm{N}-\mathrm{H} \cdots \mathrm{O}$ and $\mathrm{C}-\mathrm{H} \cdots \mathrm{O}$ hydrogen-bonding and $\pi$ interactions. Symmetry-independent molecules are shown in different colors in wireframe style (green and purple), and $\mathrm{H}$ atoms bonded to $\mathrm{C}$ atoms have been omitted for clarity. The hydrogen bonds and $\pi$ interactions are shown as blue dotted and black dashed lines, respectively.

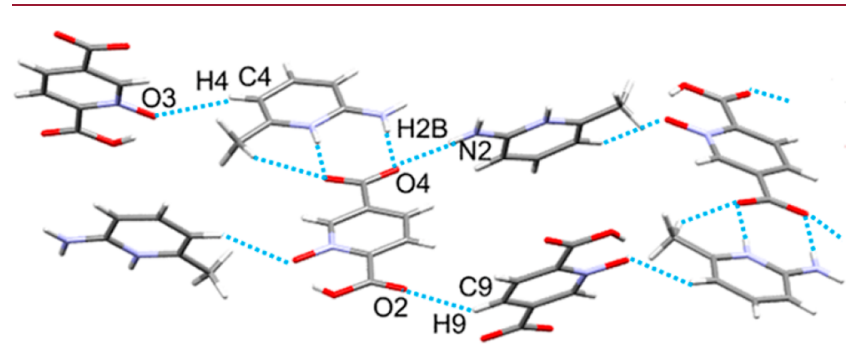

Figure 8. 1D ladder of $\mathbf{3 A}$ viewed along the $c$ axis.

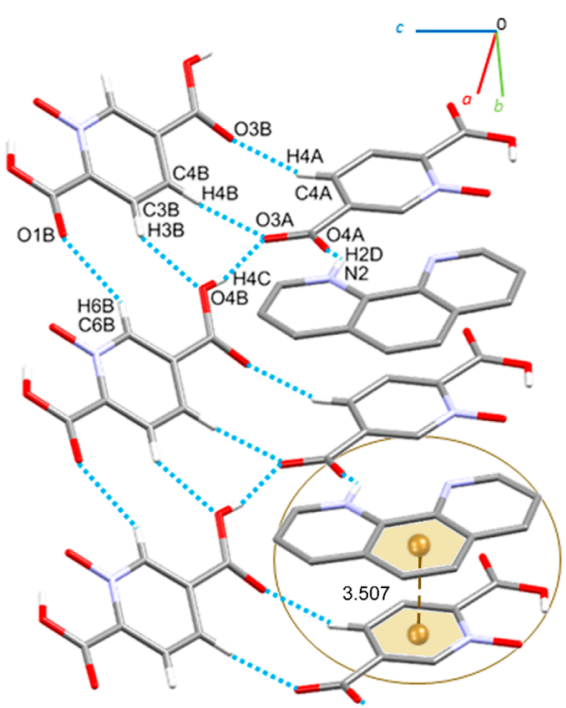

Figure 10. Representation of the $1 \mathrm{D}$ chain in 4 formed via $\mathrm{O}-\mathrm{H} \cdots \mathrm{O}$ and $\mathrm{C}-\mathrm{H} \cdots \mathrm{O}$ hydrogen-bonding and $\pi$ interactions, along the $b$ axis. The hydrogen bonds and $\pi$ interactions are shown as blue and brown dotted lines, respectively. $\mathrm{H}$ atoms bonded to $\mathrm{C}$ atoms have been omitted for clarity.

studied contacts according to the conventional approach suggested by Espinosa et al. ${ }^{42}$ and Vener et al., ${ }^{43}$ which were developed specifically for HBs.

In 1 different types of $\mathrm{N}-\mathrm{H} \cdots \mathrm{O}, \mathrm{N}-\mathrm{H} \cdots \mathrm{N}$, and $\mathrm{C}-\mathrm{H} \cdots \mathrm{N}$ intermolecular hydrogen bonds are formed via the three faces of the melaminium cation, as shown in Figure 13. A saltbridge interaction is formed via the protonated face, where two $\mathrm{N}-\mathrm{H} \cdots \mathrm{O}$ interactions are established. The distribution of critical points and bond paths indicate that each $\mathrm{H}$ bond is characterized by a bond critical point $(\mathrm{CP})$ and bond path (BP) that connects the $\mathrm{H}$ atom to the $\mathrm{N}$ or $\mathrm{O}$ atom. In Figure

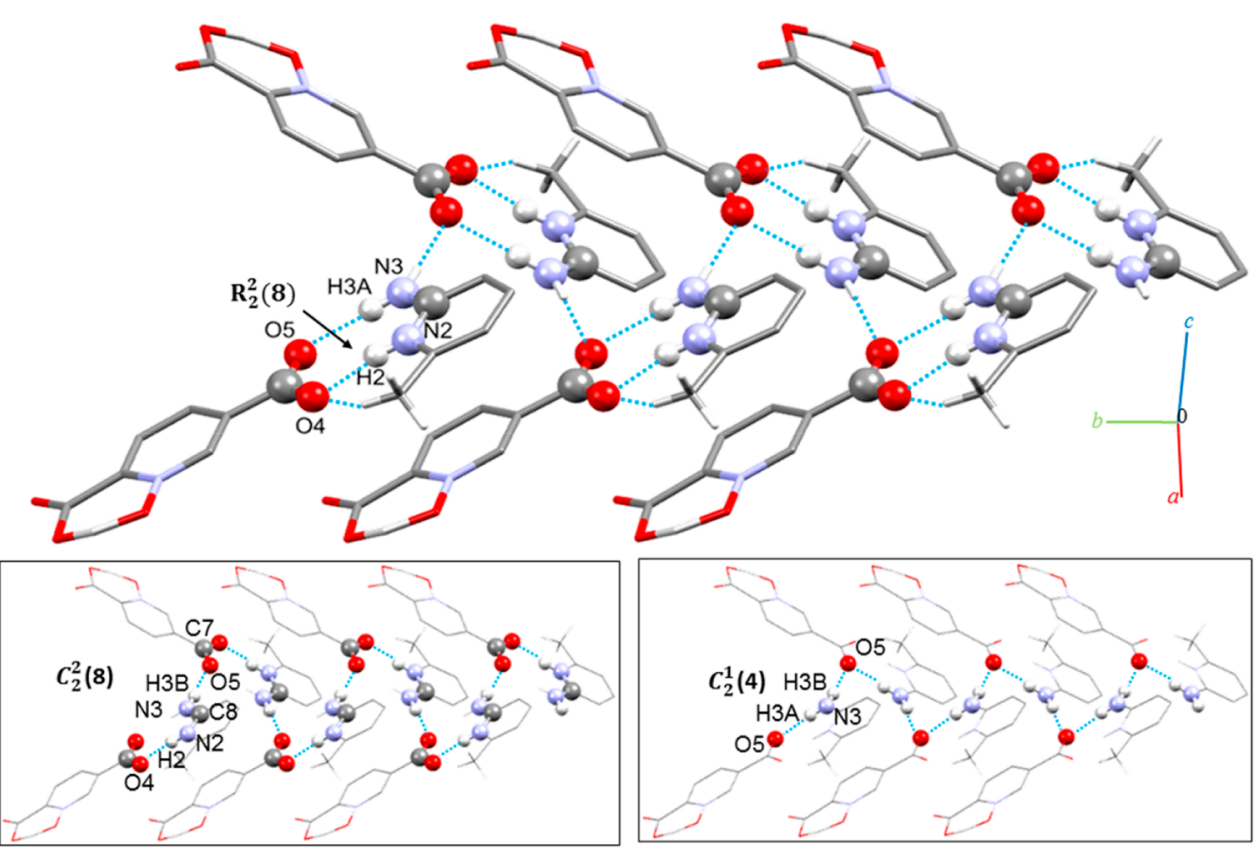

Figure 9. Schematic representation of the $1 \mathrm{D}$ zigzag chain along the $b$ axis by $\mathrm{N}-\mathrm{H} \cdots \mathrm{O}$ hydrogen bonding, with indicated graph-set notations $R_{2}^{2}(8), C_{2}^{2}(8)$, and $C_{2}{ }^{1}(4)$ in $3 B$. $\mathrm{H}$ atoms bonded to $\mathrm{C}$ atoms have been omitted for clarity. 


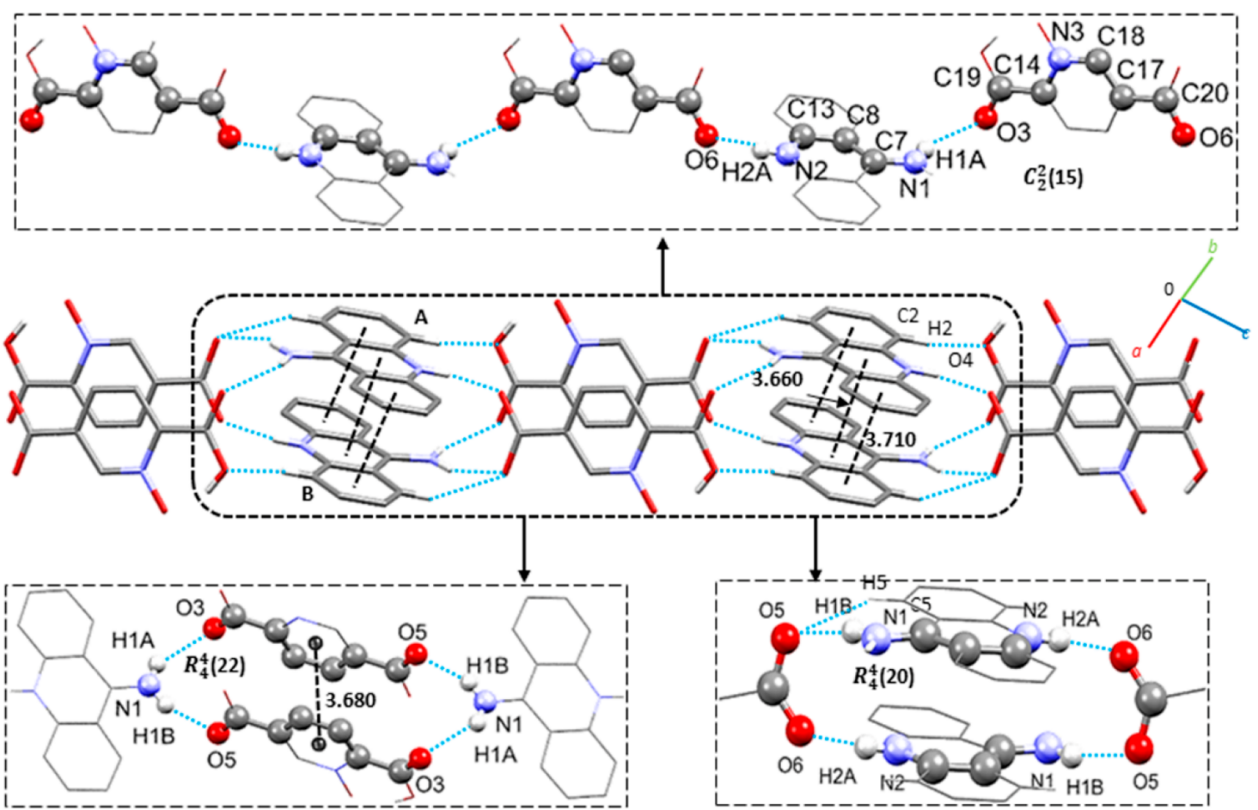

Figure 11. Representation of the $1 \mathrm{D}$ double chains along the side view by the $\mathrm{N}-\mathrm{H} \cdots \mathrm{O}$ hydrogen bonding and hydrogen-bonded motifs $\mathrm{C}_{2}^{2}(8)$, $R_{4}^{4}(20)$, and $R_{4}^{4}(22)$ in 5 . Distances are shown in $\AA$. The hydrogen bonds and $\pi$ interactions are shown as blue dotted lines and black dashed lines, respectively. $\mathrm{H}$ atoms bonded to $\mathrm{C}$ atoms have been omitted for clarity.

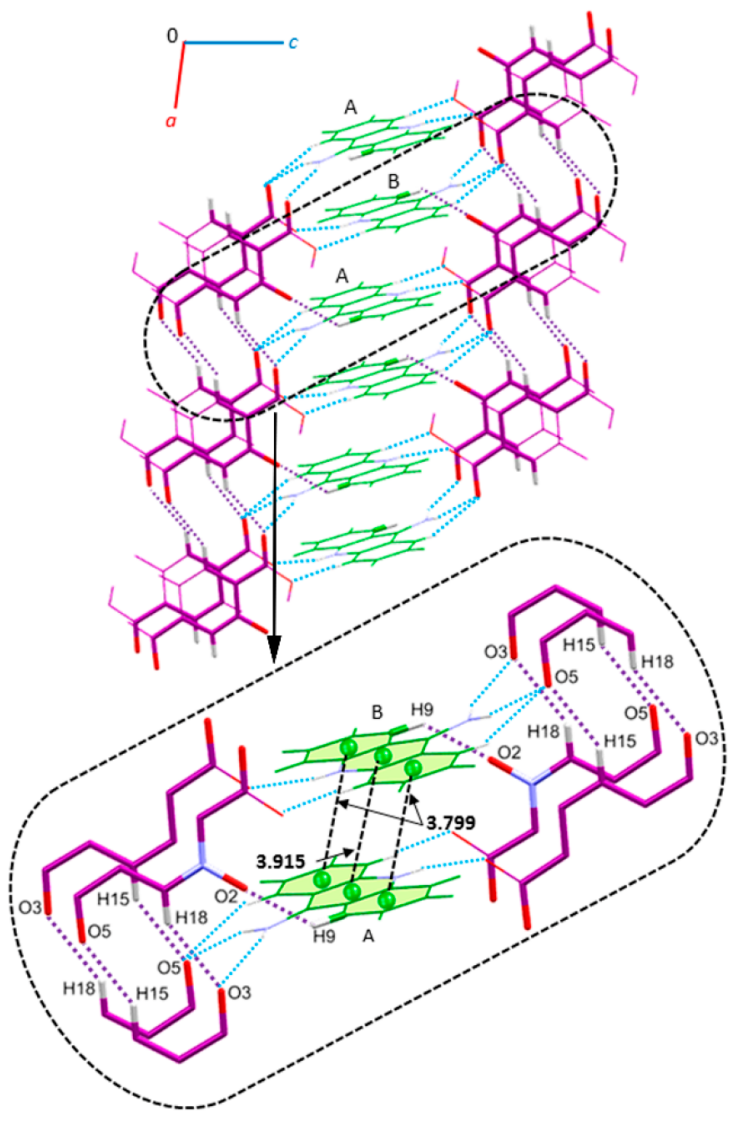

Figure 12. Extended network of the intermolecular interactions of $\mathbf{5}$, projected along the $b$ direction. Distances are shown in $\AA$. The N$\mathrm{H} \cdots \mathrm{O}$ and $\mathrm{C}-\mathrm{H} \cdots \mathrm{O}$ hydrogen bonds and $\pi$ interactions are shown as blue and purple dotted lines and black dashed lines, respectively. Symmetry-independent ions and are shown in different colors (green, purple).

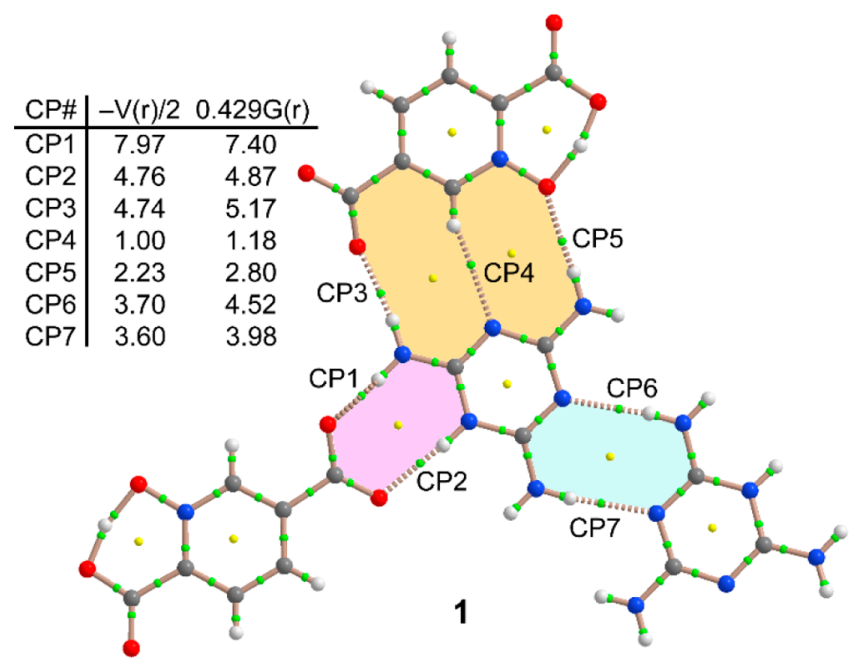

Figure 13. AIM distribution of bond and ring critical points (green and yellow spheres, respectively) and bond paths obtained for the $\mathrm{H}$ bonded assembly of compound $\mathbf{1}$. The dissociation energies of the $\mathrm{H}$ bonds using the $V(r)$ and $G(r)$ values at the bond CP are indicated (in $\mathrm{kcal} / \mathrm{mol}$ ) in the upper left corner.

13 we also summarize the binding energies (in $\mathrm{kcal} / \mathrm{mol}$ ) for each $\mathrm{H}$ bond using both methodologies: i.e., derived from the potential energy density $V(r)$ and from the Lagrangian kinetic energy $G(r)$. The values obtained using both methodologies are similar, and they reveal that the $\mathrm{N}-\mathrm{H} \cdots \mathrm{O} \mathrm{H}$ bonds are stronger, apart from that involving the $\mathrm{N}$-oxide (CP5). Interestingly, the antielectrostatic $\mathrm{N}-\mathrm{H} \cdots \mathrm{N} \mathrm{H}$ bonds in $\mathbf{1}$ (see green area in Figure 13) that are formed between the cationic melamine units and characterized by bond critical points CP6 and CP7 ( $\mathrm{H}$ bonds) are energetically favorable (around $4.0 \mathrm{kcal} / \mathrm{mol}$ ). Finally, the $\mathrm{C}-\mathrm{H} \cdots \mathrm{N} \mathrm{H}$ bond is weak $(\sim 1.0 \mathrm{kcal} / \mathrm{mol})$, as expected by taking into consideration the $\mathrm{H}$-bond donor group (aromatic $\mathrm{C}-\mathrm{H}$ bond). 
In 2 , we have studied the salt-bridge interaction and also two symmetrically equivalent $\mathrm{C}-\mathrm{H} \cdots \mathrm{O} \mathrm{H}$ bonds (characterized by CP3) that connect two (Hpydco) ${ }^{-}$anions (Figure 14).

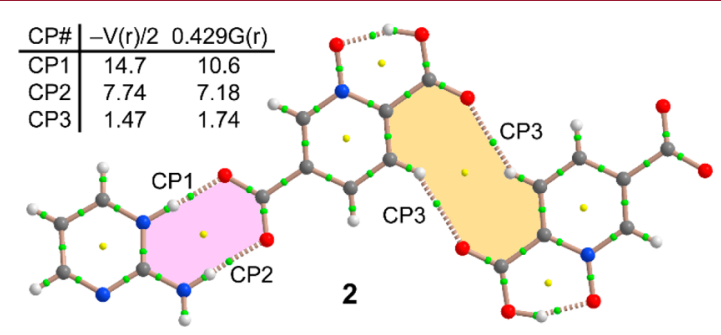

Figure 14. AIM distribution of bond and ring critical points (green and yellow spheres, respectively) and bond paths obtained for the $\mathrm{H}$ bonded assembly of compound 2. The dissociation energies of the $\mathrm{H}$ bonds obtained using the $V(r)$ and $G(r)$ values at the bond CP are indicated (in $\mathrm{kcal} / \mathrm{mol}$ ) in the upper left corner.

The interaction energy of the salt bridge (characterized by CP1 and CP2) is significantly stronger than that observed in $\mathbf{1}$ (melamine cation), which is likely due to the smallest delocalization of the positive charge in the 2-aminopyrimidinium cation in comparison to melaminium. In fact, the $\mathrm{N}^{+}-$ $\mathrm{H} \cdots \mathrm{O}$ bond is stronger than the exocyclic $\mathrm{N}-\mathrm{H} \cdots \mathrm{O}$ bond in 2 and the opposite is observed in 1, thus confirming the stronger delocalization in the latter. Finally, each antielectrostatic C$\mathrm{H} \cdots \mathrm{O} \mathrm{H}$ bond established between the anionic moieties contributes $1.47 / 1.74 \mathrm{kcal} / \mathrm{mol}$.

The QTAIM analyses of polymorphs 3 A,B are shown in Figure 15. In both compounds the strongest $\mathrm{H}$-bonding interaction corresponds to the $\mathrm{N}^{+}-\mathrm{H} \cdots \mathrm{O}$ contact of the salt-

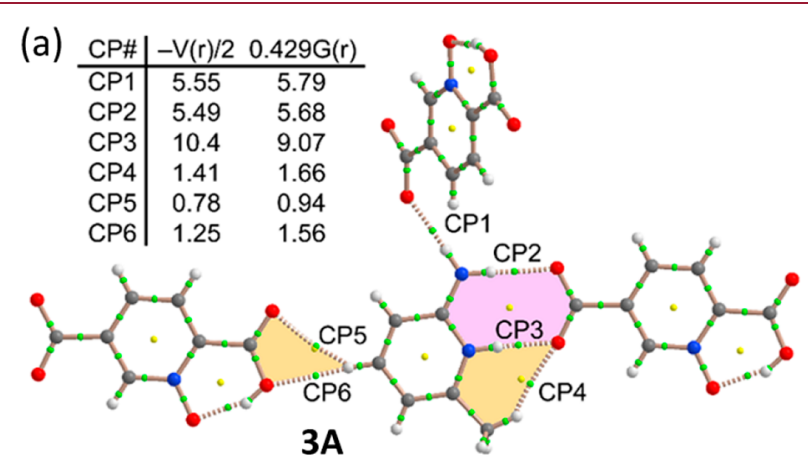

(b)

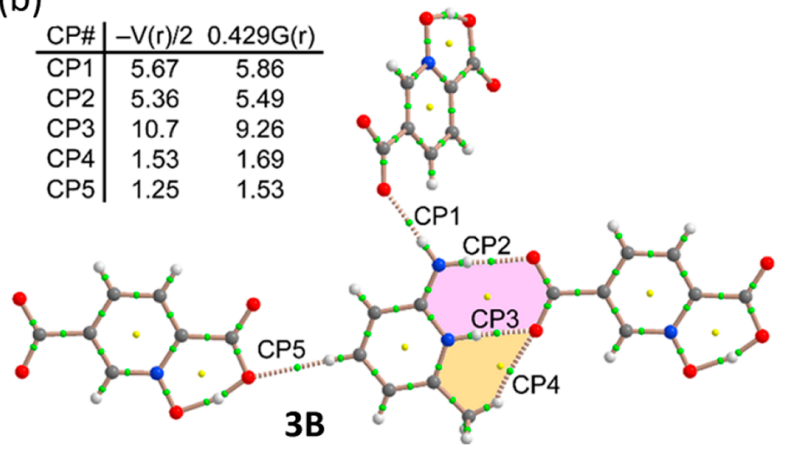

Figure 15. AIM distribution of bond and ring critical points (green and yellow spheres, respectively) and bond paths obtained for the $\mathrm{H}$ bonded assemblies of (a) 3A and (b) 3B. The dissociation energies of the $\mathrm{H}$ bonds calculated using the $V(r)$ and $G(r)$ values at the bond $\mathrm{CP}$ are indicated (in $\mathrm{kcal} / \mathrm{mol}$ ) in the upper left corners. bridge interaction (CP3), in a manner similar to that for 2 . The presence of a methyl group in the aminopyridine ring assists the salt bridge formation with an additional $\mathrm{C}-\mathrm{H} \cdots \mathrm{O}$ interaction $(1.41 / 1.66 \mathrm{kcal} / \mathrm{mol}, \mathrm{CP} 4)$. The main difference between both polymorphs is the interaction of the cationic moiety with the carboxylic group engaged in the intramolecular $\mathrm{H}$-bond with the $\mathrm{N}$-oxide. In 3A, the QTAIM analysis suggests the formation of a bifurcated $\mathrm{H}$ bond with the $\mathrm{C}-\mathrm{H}$ in a para position relative to the protonated $\mathrm{N}$ atom, whereas in compound $\mathbf{3 B}$ the interaction is characterized by the presence of a single bond $\mathrm{CP}$ and $\mathrm{BP}$. In any case, these $\mathrm{C}-\mathrm{H} \cdots \mathrm{O}$ contacts are the weakest interactions of both assemblies, which is in line with previous results.

In 4 the salt-bridge interaction cannot be formed, in contrast to $\mathbf{1}, \mathbf{2}$, and $\mathbf{3 A}, \mathbf{B}$, where it is the most favored interaction. Instead, the anionic carboxylate group interacts with both the neutral $\mathrm{H}_{2}$ pydco moiety and the monoprotonated 1,10-phenanthrolinium cation (see Figure 16). Un-

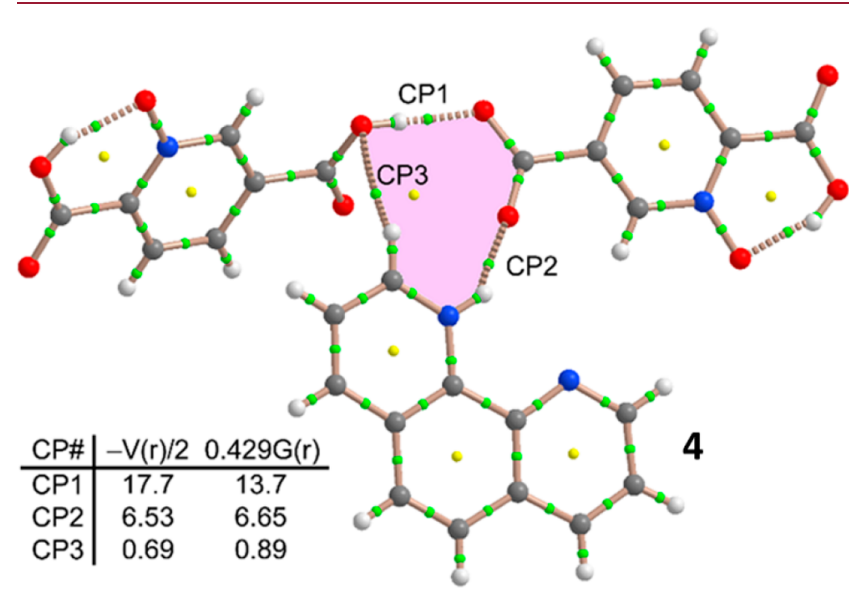

Figure 16. AIM distribution of bond and ring critical points (green and yellow spheres, respectively) and bond paths obtained for the $\mathrm{H}$ bonded assembly of compound 4 . The dissociation energies of the $\mathrm{H}$ bonds obtained using the $V(r)$ and $G(r)$ values at the bond CP are indicated (in $\mathrm{kcal} / \mathrm{mol}$ ) in the upper left corner.

expectedly, the strongest interaction corresponds to the $\mathrm{O}-$ $\mathrm{H} \cdots \mathrm{O} \mathrm{H}$ bond (CP1) instead to the electrostatically enhanced (CP2) $\mathrm{N}^{+}-\mathrm{H} \cdots \mathrm{O} \mathrm{H}$ bond. Finally, the distribution of bond CPs and BPs also reveals the existence of an additional and weak $\mathrm{C}-\mathrm{H} \cdots \mathrm{O}$ interaction (CP3, 0.69/0.89 $\mathrm{kcal} / \mathrm{mol}$ ) involving an aromatic $\mathrm{C}-\mathrm{H}$ group of the 1,10-phenanthrolinium cation and the carboxylic group.

Figure 17 displays the $\mathrm{H}$-bonded interactions involving the protonated 9-aminoacridine. The amino group establishes two $\mathrm{H}$ bonds with two (Hpydco) ${ }^{-}$units (characterized by CP1 and $\mathrm{CP} 2$ critical points). The $\mathrm{H}$ bond characterized by the critical point CP2 is stronger than that of CP1 due to the anionic nature of the $\mathrm{H}$-bond acceptor in the former (carboxylate). The (Hpydco) ${ }^{-}$units are also stabilized by the formation of $\pi$ stackings which are characterized by four bond CPs and bond paths interconnecting both anions. As expected, the strongest $\mathrm{H}$ bond corresponds to the electrostatically enhanced $\mathrm{N}^{+}-\mathrm{H} \cdots$ $\mathrm{O}^{-} \mathrm{H}$ bond (CP4), in agreement with the shortest distance.

Hirshfeld Surface Analysis. Hirshfeld surface (HS) ${ }^{44}$ analysis and analysis of 2D fingerprint plots (2D FPs) derived from them ${ }^{45}$ offer a unique means of exploration of intermolecular contacts within the crystal structures. ${ }^{46-50}$ One of the greatest benefits that comes from using these 


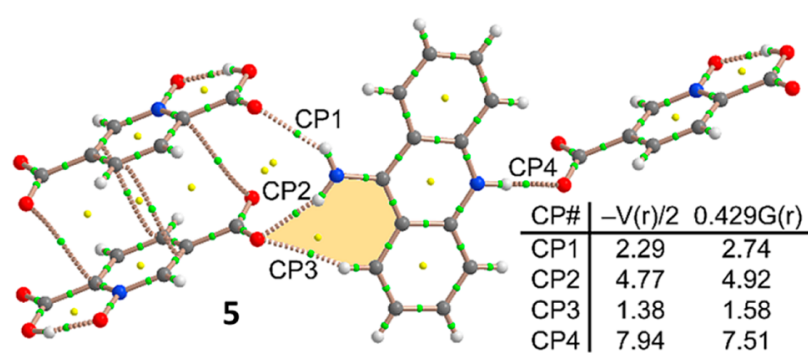

Figure 17. AIM distribution of bond and ring critical points (green and yellow spheres, respectively) and bond paths obtained for the $\mathrm{H}$ bonded assembly of compound 5 . The dissociation energies of the $\mathrm{H}$ bonds obtained using the $V(r)$ and $G(r)$ values at the bond CP are indicated (in $\mathrm{kcal} / \mathrm{mol}$ ) in the lower right corner.

techniques is the possibility for decomposition of the HS into regions dominated by specific contacts, which in turn allows one to calculate percentage contributions of various contact classes (e.g., $\mathrm{H} \cdots \mathrm{H}$ or $\mathrm{O} \cdots \mathrm{H}$ ) to the HS. In this way, supramolecular environments of molecules can be systematically compared to each other in quantitative terms. This approach proved to be particularly helpful in the identification of substituent, counterion, and (de)protonation effects on the HSs of related compounds. $51-54$

From the viewpoint of $\mathrm{HS}$ analysis of supramolecular interactions, a very interesting feature of compounds $\mathbf{1 - 5}$ is that they combine two aspects of a proton transfer. As already indicated in previous sections, these compounds belong to the salt class (with the exception of $\mathbf{5}$, which should be referred to as an "ionic cocrystal"), since all feature intermolecular proton transfer. Additionally, the presence of a carboxylate group next to the $\mathrm{N}$-oxide creates a possibility for an intramolecular transfer of protons between oxygen acceptors, giving rise to the tautomerism phenomenon. Accordingly, HS analysis should target and assess the effect both of these proton transfer phenomena on the properties of HSs. To this end, we have drawn $d_{\text {norm }}$-mapped HSs of $\mathrm{Hpydco}^{-}(1-4,5 \mathrm{~A}, 6)$ and $\mathrm{H}_{2}$ pydco (5B) species (Figure S9, Supporting Information) as well as calculated contact-decomposed 2D FPs (Figures S10S15, Supporting Information). In Table 2 are given percentage contributions of respective contacts for each HS.

Table 2. Percentage Contributions of Intermolecular Contacts to the HSs of $1-5$

\begin{tabular}{crrrrrrr} 
entry & \multicolumn{1}{c}{$\mathbf{1}$} & $\mathbf{2}$ & $\mathbf{3 A}$ & $\mathbf{3 B}$ & $\mathbf{4 a}$ & $\mathbf{4 b}$ & $\mathbf{5}$ \\
$\mathrm{O} \cdots \mathrm{H}$ & 42.3 & 47.4 & 45.3 & 46.7 & 51.0 & 51.6 & 49.5 \\
$\mathrm{H} \cdots \mathrm{H}$ & 16.4 & 15.1 & 21.9 & 21.0 & 14.5 & 15.3 & 22.8 \\
$\mathrm{C} \cdots \mathrm{H}$ & 9.6 & 11.1 & 9.3 & 9.3 & 6.9 & 12.8 & 10.1 \\
$\mathrm{C} \cdots \mathrm{O}$ & 12.3 & 8.1 & 11.1 & 10.8 & 4.4 & 10.6 & 4.5 \\
$\mathrm{C} \cdots \mathrm{C}$ & 3.2 & 5.9 & 5.6 & 5.6 & 13.8 & 2.9 & 6.0 \\
$\mathrm{~N} \cdots \mathrm{H}$ & 5.7 & 4.5 & 2.1 & 2.1 & 3.0 & 0.7 & 3.2 \\
$\mathrm{O} \cdots \mathrm{O}$ & 3.7 & 3.5 & 0.7 & 0.6 & 1.8 & 2.2 & 2.3 \\
$\mathrm{~N} \cdots \mathrm{C}$ & 5.2 & 3.0 & 2.2 & 2.2 & 4.4 & 2.0 & 0.3 \\
\hline
\end{tabular}

A general description of features of HSs and 2D FPs of 1-5 is provided in the Supporting Information, but here we will explore in depth specific HS properties of $\mathbf{3 A}, \mathbf{B}, \mathbf{4}$, and $\mathbf{5}$.

We will start from the analysis of protonation-dependent supramolecular roles that are played by $\mathrm{Hpydco}^{-}$and $\mathrm{H}_{2}$ pydco species. $\mathbf{4}$ is an example of an ionic cocrystal, since it involves both a $\mathrm{Hpydco}^{-}$anionic (4a) and $\mathrm{H}_{2}$ pydco (4b) neutral molecule, apart from the phenanthrolinium cation. Note that small letters are used here to distinguish $\mathrm{Hpydco}^{-}$and $\mathrm{H}_{2}$ pydco molecules. The presence of two molecules of different protonation states in one crystal lattice allows reliable side by side comparisons of their contact contributions to the HS (Table 2). Indeed, quite strikingly, if one compares the percentage of $\mathrm{O} \cdots \mathrm{H}$ contacts, it turns out that the protonation state does not significantly affect the relative contribution of this contact ( $51.0 \%$ vs $51.6 \%$ for $\mathbf{4 a} \mathbf{a} \mathbf{b}$, respectively). In fact, the largest differences in contact contributions due to protonation emerge not in contacts primarily associated with strong hydrogen bonding $(\mathrm{O} \cdots \mathrm{H}$ and $\mathrm{N} \cdots \mathrm{H})$ but in those regarded rather as supporting contacts. For instance, a dramatic difference is noted for C...C contacts $(13.8 \%$ vs $2.9 \%$ for $\mathbf{4 a}, \mathbf{b}$, respectively), $\mathrm{C} \cdots \mathrm{H}$ contacts $(6.9 \%$ vs $12.8 \%$ for $\mathbf{4 a , b}$, respectively), and $\mathrm{C} \cdots \mathrm{O}$ contacts $(4.4 \%$ vs $10.6 \%$ for $\mathbf{4 a}, \mathbf{b}$, respectively). The location of these contacts is presented in Figure 18a. These differences in contact contributions are easy

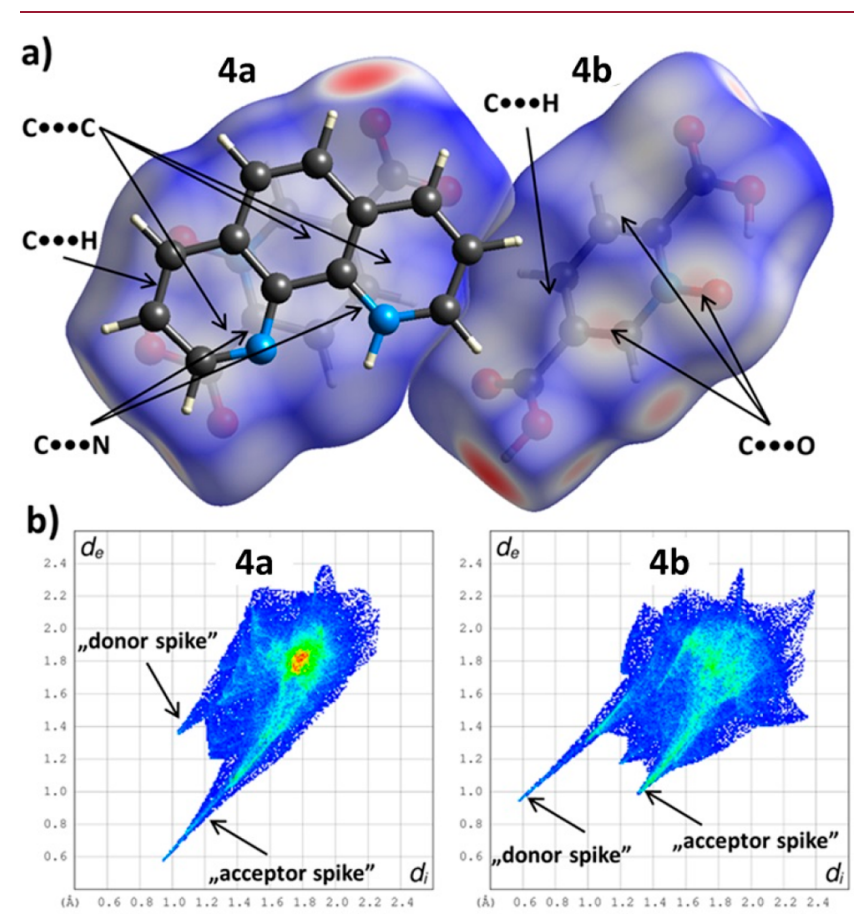

Figure 18. (a) Semitransparent HSs mapped with the $d_{\text {norm }}$ function for $4 \mathbf{a}$ (left) and $\mathbf{4 b}$ (right). The most important intermolecular interactions are indicated with arrows; all red areas that are not described on the picture indicate $\mathrm{O} \cdots \mathrm{H}$ contacts. (b) 2D FPs of $4 \mathrm{a}$ (left) and $\mathbf{4 b}$ (right).

to understand if one appreciates the various structural roles played by $\mathrm{Hpydco}^{-}$and $\mathrm{H}_{2}$ pydco molecules. As shown in Figure 10 in Description of the Crystal Structures, Hpydco $^{-}(4 a)$ participates in extensive charge-assisted $\pi-\pi$ stacking with phenanthrolinium cation, which is imposing a high contribution of $\mathrm{C} \cdots \mathrm{O}$ and $\mathrm{C} \cdots \mathrm{C}$ contacts. Note that the former contacts arise from the interaction of carboxylic groups with the $\pi$-conjugated plane of aromatic cations. On the other hand, $\pi-\pi$ stacking with such a large aromatic molecule effectively shields $\mathrm{Hpydco}^{-}$from $\mathrm{C}-\mathrm{H} \cdots \pi$ interactions, which is clearly reflected in a diminished share of $\mathrm{C} \cdots \mathrm{H}$ contacts for 4a.

As seen in Figure 18b, 2D FPs of 4a,b are largely different in both occupied area and overall shape. Strong hydrogen bonding is reflected in so-called "spikes", pointing to the 
lower left side of each plot. The upper spike corresponds to the hydrogen bond donor sites that form $\mathrm{C}-\mathrm{H} \cdots \mathrm{O}, \mathrm{N}-\mathrm{H} \cdots \mathrm{O}$, and $\mathrm{O}-\mathrm{H} \cdots \mathrm{O}$ interactions, while the lower spike represents all $\mathrm{O}$ accepting sites of these interactions, as determined from contact-decomposed FP plots (Figures S14 and S15 in the Supporting Information). It is clear that despite essentially the same contribution of $\mathrm{O} \cdots \mathrm{H}$ contacts $(51.0 \%$ vs $51.6 \%$ for $\mathbf{4 a}, \mathbf{b}$, respectively) the protonation-dependent differences in $2 \mathrm{D}$ FP properties are outstandingly sharp.

For a broader perspective, the above observations regarding $\mathrm{O} \cdots \mathrm{H}$ contacts should be put into the context of the other systems for which the protonation-dependent HS properties have been investigated. For example, we have very recently found that protonation of melamine is strongly correlated with a higher participation of strong hydrogen bonding contacts to oxygen acceptors $(\mathrm{O} \cdots \mathrm{H})$. Indeed, monoprotonated melaminium species $\left(\mathrm{Hme}^{+}\right)$were found to feature a $50-100 \%$ increase in $\mathrm{O} \cdots \mathrm{H}$ contacts vs nonprotonated melamine and at least a 4-fold increase in $\mathrm{O} \cdots \mathrm{H}$ contacts for biprotonated melaminium species $\left(\mathrm{H}_{2} \mathrm{me}^{2+}\right)$, again in comparison to neutral melamine. ${ }^{53}$ Clearly, melamine is a basic compound and hence a more "apples to apples" comparison of $\mathrm{Hpydco}^{-}$and $\mathrm{H}_{2}$ pydco contact contributions necessitates consideration of acidic species. To the best of our knowledge, the only study that targeted the effect of deprotonation on the HS and HSrelated properties was that of Białek et al. ${ }^{54}$ In this study, no significant change in percentage contribution of $\mathrm{O} \cdots \mathrm{H}$ contacts to the HS has been identified for naphthalene-1,5-diphosphonic acid with different phosphonic species $\left(-\mathrm{PO}_{3} \mathrm{H}_{2}\right.$ and $\left.-\mathrm{PO}_{3} \mathrm{H}^{-}\right)$, which is accordance with our results.

When all these considerations are taken together, the observed differences in quantitative $\mathrm{HS}$ properties of $\mathrm{Hpydco}^{-}$ and $\mathrm{H}_{2}$ pydco species are predominantly reflected in shares of secondary contacts such as $\mathrm{C} \cdots \mathrm{C}, \mathrm{C} \cdots \mathrm{O}$, and $\mathrm{C} \cdots \mathrm{H}$, rather than in contact contributions of strong interactions $(\mathrm{O} \cdots \mathrm{H}, \mathrm{N} \cdots \mathrm{H})$. This is because acid molecules in the deprotonated state experience approximately the same amount of strong hydrogen bonding as in the neutral state but engage in a different set of weaker contacts.

Having established the effect of protonation state of pydco species on HSs and their properties, we moved to the investigation of the intramolecular proton transfer on the HSs of molecules. To the best of our knowledge, this issue has not been investigated thus far. For this reason, it is not even known whether HS analysis is able to reliably pinpoint differences between two tautomers. Indeed, proton migration is an intramolecular event, which suggests that its effect on the HS properties (which in general, characterizes intermolecular contacts) of tautomers should not be profound. On the other hand, intramolecular proton transfer may be assisted by an overall change in supramolecular environment of a molecule, consequently leading to e.g. a subtly different set of interactions experienced by the molecule.

In order to explore the capability of HS analysis to investigate intramolecular proton transfer, we also looked at the HS properties of polymorphic compounds $\mathbf{3 A}, \mathbf{B}$, since they differ in the proton localization: in $\mathbf{3 A}$ the proton is localized at the carboxylic oxygen atom, while in $3 \mathrm{~B}$ it occupies the central position between the oxygen atoms of carboxylate and $\mathrm{N}$ oxide.

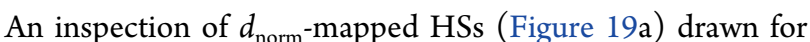
$\mathrm{Hpydco}^{-}$units in $\mathbf{3 A}, \mathbf{B}$ shows that they closely resemble each other; their main feature is the presence of two red spots that a)

b)

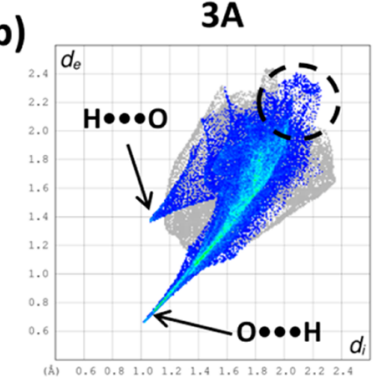

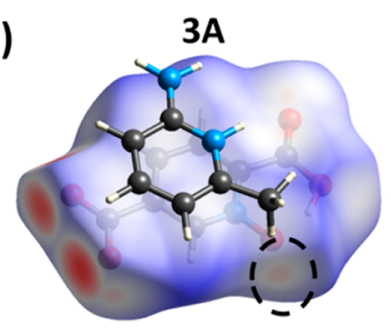

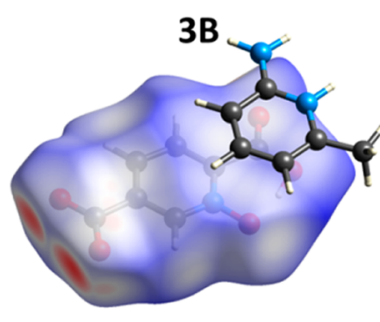

3B

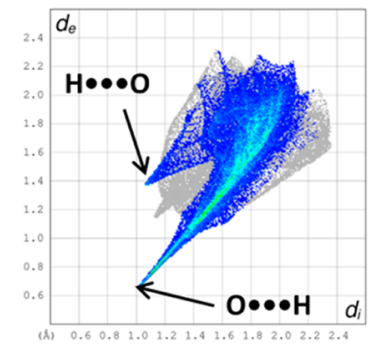

Figure 19. (a) Semitransparent HS mapped with the $d_{\text {norm }}$ function for polymorphs $3 \mathbf{A}$ (left) and 3B (right). (b) Contact-decomposed $(\mathrm{H} \cdots \mathrm{O}) 2 \mathrm{D}$ FPs of $\mathbf{3 A}, \mathbf{B}$.

correspond to strong $\mathrm{N}-\mathrm{H} \cdots \mathrm{O}$ contacts, contributing to $\mathrm{HB}$ $R_{2}{ }^{2}(8)$ ring motifs. There is, however, a very subtle difference in the environment of the $N$-oxide functional group: in the case of $3 \mathbf{A}$ one sees a faint red area, whereas this is not present in 3B (Figure 19a). This contact originates from weak $\mathrm{C}_{\mathrm{ar}}-\mathrm{H} \cdots \mathrm{O}$ $\mathrm{HBs}$ between (H2a-6mpy) ${ }^{+}$and $\mathrm{Hpydco}^{-}$. Contact-decomposed $(\mathrm{H} \cdots \mathrm{O})$ 2D FPs of 3A,B show differences only in regions of high $d_{\mathrm{i}}+d_{\mathrm{e}}$ values, i.e. where weak, distant contacts are reflected (denoted as a dashed oval in Figure 19b), highlighting the close similarity of supramolecular environments of $\mathrm{Hpydco}^{-}$species.

Contact contributions to the HS characterizing $\mathbf{3 A , B}$ are given in Table 2. It is apparent that values of percentage shares of contacts to the HS are quite similar, with the biggest difference of $0.9 \%$ visible in $\mathrm{H} \cdots \mathrm{H}$ contacts $(21.9 \%$ vs $21.0 \%$ for $3 \mathbf{A}, \mathbf{B}$, respectively). This raises the question of whether slightly different contact contributions to the HS of $3 \mathbf{A}, \mathbf{B}$ originate from their polymorphic structures or rather from the intramolecular shift of the hydrogen atom itself. In order to explore this issue, we have calculated contact contributions to the HS for specially modified crystal structures of $\mathbf{3 A}, \mathbf{B}$. The applied modification consists of the shifting of a hydrogen atom that resides between the carboxylic oxygen atom and $N$ oxide, so that a competing tautomer is obtained. More specifically, in the case of $\mathbf{3 A}$ the hydrogen atom has been placed at the central position between oxygen atoms (3Amod), while for $3 \mathbf{B}$ the hydrogen atom has been placed near the carboxylic oxygen atom (3B-mod). As shown in Table S3 in the Supporting Information, the position of the mobile hydrogen atom does not have any significant effect on contacts that contribute to HS properties, on the basis of a comparison of 3A-mod and 3B-mod to 3A,B, respectively. Consequently, minor differences in contact landscapes of $\mathbf{3 A , B}$ (Table 2) can be ascribed to various crystal environments, but not to intramolecular proton transfer (tautomerization). In light of these results it is suggested that HS analysis is not a sensitive tool for the differentiation of tautomeric structures.

Concluding Remarks. In summary, we prepared and characterized a series of acid-base compounds involving $\mathrm{Hpydco}^{-}$as the anion and several $\mathrm{N}$-containing aromatic bases 
as cations. An important observation is that the hydrogenbonded motif $R_{2}^{2}(8)$ is present in all crystals structures that involve the $\alpha$-aminopyridinium moiety (compounds 1, 2, and 3A,B). The use of large polycyclic organic bases (phenanthroline and 9-aminoacridine, compounds 4 and 5) resulted in the formation of hydrogen-bond networks devoid of this motif, which however has been replaced by extensive $\pi-\pi$-stacking and $\mathrm{C}-\mathrm{H} \cdots \pi$ interactions. Accordingly, the presence of different kinds of cations predetermines how $\mathrm{Hpydco}^{-}$will participate in the crystal packing.

We have computed the interaction energies of the individual $\mathrm{H}$-bonding interactions observed in the solid state of compounds 1-5, which led us to several interesting conclusions. One is that positively charged melaminium species in $\mathbf{1}$ form antielectrostatic $\mathrm{N}-\mathrm{H} \cdots \mathrm{N} \mathrm{H}$ bonds which are energetically favorable (around $4.0 \mathrm{kcal} / \mathrm{mol}$ ). The other is that charge-assisted hydrogen bonding does not always offer an advantage over "noncharged" hydrogen bonds. For example, the $\mathrm{N}^{+}-\mathrm{H} \cdots \mathrm{O}$ bond is stronger than the exocyclic $\mathrm{N}-\mathrm{H} \cdots \mathrm{O}$ bond in 2, whereas the opposite relationship is observed in $\mathbf{1}$, which suggests stronger delocalization in the latter. One more example of that is 4 , whose strongest interaction in the hydrogen-bonding net corresponds to the $\mathrm{O}-\mathrm{H} \cdots \mathrm{O} \mathrm{H}$ bond rather than to the electrostatically "enhanced" $\mathrm{N}^{+}-\mathrm{H} \cdots \mathrm{O} \mathrm{H}$ bond.

Taken together, the energetic study might be useful to rationalize cocrystallization modes of pyridine-2,5-dicarboxylic acid $\mathrm{N}$-oxide derivatives.

The effect of the protonation state of pydco species on HSs 2D FP properties has been investigated. It is observed that differences in $\mathrm{HS}$ properties of $\mathrm{Hpydco}^{-}$and $\mathrm{H}_{2}$ pydco species, in quantitative terms, are mainly reflected in shares of secondary contacts such as $\mathrm{C} \cdots \mathrm{C}, \mathrm{C} \cdots \mathrm{O}$, and $\mathrm{C} \cdots \mathrm{H}$, rather than in contact contributions of strong interactions $(\mathrm{O} \cdots \mathrm{H}$, $\mathrm{N} \cdots \mathrm{H}$ ). On the other hand, the biggest effect on the appearance of 2D FPs of $\mathrm{Hpydco}^{-}$and $\mathrm{H}_{2}$ pydco species is different sets (either primarly accepting or donating) of $\mathrm{O} \cdots \mathrm{H}$ contacts to these molecules.

We have also investigated the usefulness of HS analysis for a comparison of polymorphic structures containing species with intramolecular proton transfer. We found the bulk of qualitative differences in $\mathrm{HS}$ and 2D FP properties are only due to various crystal environments and are not due to intramolecular proton transfer. Accordingly, we suggest that HS analysis is not a sensitive tool for the differentiation of tautomeric structures in similar crystal environments.

\section{ASSOCIATED CONTENT}

\section{SI Supporting Information}

The Supporting Information is available free of charge at https://pubs.acs.org/doi/10.1021/acs.cgd.9b01475.

Selected bond lengths $(\AA)$ and valence angles (deg) for 1-5, selected hydrogen bond geometries, infrared spectra, additional packing figures, Cartesian coordinates, and Hirshfeld surface analysis (PDF)

\section{Accession Codes}

CCDC 1554218-1554220, 1554228-1554229, and 1554231 contain the supplementary crystallographic data for this paper. These data can be obtained free of charge via www.ccdc.cam.ac.uk/data_request/cif, or by emailing data_request@ccdc. cam.ac.uk, or by contacting The Cambridge Crystallographic
Data Centre, 12 Union Road, Cambridge CB2 1EZ, UK; fax: +441223336033.

\section{AUTHOR INFORMATION}

\section{Corresponding Authors}

Masoud Mirzaei - Department of Chemistry, Faculty of Science, Ferdowsi University of Mashhad, Mashhad, Iran; - orcid.org/ 0000-0002-7256-4601; Email: mirzaeesh@um.ac.ir; Fax: +9838796416

Jan K. Zaręba - Advanced Materials Engineering and Modelling Group, Wroctaw University of Science and Technology, 50370 Wroctaw, Poland; 이잉.org/0000-0001-6117-6876; Email: jan.zareba@pwr.edu.pl

Antonio Frontera - Department of Chemistry, Universitat de les Illes Balears, 07122 Palma, Baleares, Spain; (1) orcid.org/ 0000-0001-7840-2139; Email: toni.frontera@uib.es; Fax: +34 971173426

\section{Authors}

Fereshteh Sadeghi - Department of Chemistry, Faculty of Science, Ferdowsi University of Mashhad, Mashhad, Iran

Krešimir Molčanov - Rudjer Boškovic Institute, HR-10000 Zagreb, Croatia

Rosa M. Gomila - Department of Chemistry, Universitat de les Illes Balears, 07122 Palma, Baleares, Spain

Complete contact information is available at:

https://pubs.acs.org/10.1021/acs.cgd.9b01475

\section{Author Contributions}

The manuscript was written through contributions of all authors. All authors have given approval to the final version of the manuscript.

Notes

The authors declare no competing financial interest.

\section{ACKNOWLEDGMENTS}

M.M. acknowledges financial support by the Ferdowsi University of Mashhad. M.M. is supported by the Iran Science Elites Federation and Zeolite and Porous Materials Committee of Iranian Chemical Society. M.M. gratefully acknowledges the Cambridge Crystallographic Data Centre (CCDC) for access to the CSD Enterprise. J.K.Z. acknowledges financial support from the Wroclaw University of Science and Technology. J.K.Z. is supported by the Foundation for Polish Science. A.F. thanks MINECO/AEI of Spain (project CTQ2017-85821-R FEDER funds) for financial support.

\section{REFERENCES}

(1) Steed, J. W.; Atwood, J. L.; Gale, P. A. Definition and Emergence of Supramolecular Chemistry. Supramolecular Chemistry: From Molecules to Nanomaterials; Wiley: 2012.

(2) Steed, J. W.; Atwood, J. L. Supramolecular Chemistry, 2nd ed.; Wiley: 2009.

(3) Brammer, L. Developments in Inorganic Crystal Engineering. Chem. Soc. Rev. 2004, 33, 476-489.

(4) Desiraju, G. R. IUCrJ 2016, 3, 1-2.

(5) Aitipamula, S.; Nangia, A. Polymorphism: Fundamentals and Applications. Supramolecular Chemistry: From Molecules to Nanomaterials; Wiley: 2012.

(6) Bernstein, J. Polymorphism - A Perspective. Cryst. Growth Des. 2011, 11, 632-650.

(7) Brog, J. P.; Chanez, C. L.; Crochet, A.; Fromm, K. M. Polymorphism, What It Is and How to Identify It: A Systematic Review. RSC Adv. 2013, 3, 16905-16931. 
(8) Mirzaei, M.; Eshtiagh-Hosseini, H.; Shamsipur, M.; Saeedi, M.; Ardalani, M.; Bauzá, A.; Mague, J. T.; Frontera, A.; Habibi, M. Importance of Polarization Assisted/Resonance Assisted Hydrogen Bonding Interactions and Unconventional Interactions in Crystal Formations of Five New Complexes Bearing Chelidamic Acid Through a Proton Transfer Mechanism. RSC Adv. 2015, 5, 7292372936.

(9) Eftekhar, M.; Mirzaei, M.; Hassanpoor, A.; Khosravi, I.; Bauzá, A.; Mague, J. T.; Frontera, A. The First Mixed-Ligand Coordination Compound Involving 8-Aminoquinoline and Pyridine-2,6-Dicarboxylic Ligands: Synthesis, X-Ray Crystal Structure and DFT Studies. J. Coord. Chem. 2015, 68, 3599-3610.

(10) Eshtiagh-Hosseini, H.; Mirzaei, M.; Biabani, M.; Lippolis, V.; Chahkandi, M.; Bazzicalupi, C. Insight into the Connecting Roles of Interaction Synthons and Water Clusters Within Different Transition Metal Coordination Compounds of Pyridine-2,5-Dicarboxylic Acid: Experimental and Theoretical Studies. CrystEngComm 2013, 15, 6752-6768.

(11) Mirzaei, M.; Eshtiagh-Hosseini, H.; Bazargan, M. Syntheses and X-Ray Crystal Structure Studies of Four New Coordination Complexes and Salts Based on Proton-Transferred Pyridine-2,6dicarboxylic Acid N-Oxide. Res. Chem. Intermed. 2015, 41, 97859803.

(12) Bazargan, M.; Mirzaei, M.; Eshtiagh-Hosseini, H.; Mague, J. T.; Bauzá, A.; Frontera, A. Synthesis, X-Ray Characterization and DFT Study of a Novel Fe(III)-Pyridine-2,6-Dicarboxylic Acid N-Oxide Complex with Unusual Coordination Mode. Inorg. Chim. Acta 2016, $449,44-51$

(13) Shahbazi, M.; Mehrzad, F.; Mirzaei, M.; Eshtiagh-Hosseini, H.; Mague, J. T.; Ardalani, M.; Shamsipur, M. Synthesis, Single Crystal XRay Characterization, and Solution Studies of $\mathrm{Zn}(\mathrm{II})-, \mathrm{Cu}(\mathrm{II})-, \mathrm{Ag}(\mathrm{I})$ And $\mathrm{Ni}(\mathrm{II})$-Pyridine-2,6-Dipicolinate $\mathrm{N}$-Oxide Complexes with Different Topologies and Coordination Modes. Inorg. Chim. Acta 2017, 458, 84-96.

(14) Hosseini-Hashemi, Z.; Mirzaei, M.; Jafari, A.; Hosseinpour, P.; Yousefi, M.; Frontera, A.; LariDashtbayaz, M.; Shamsipur, M.; Ardalani, M. Effects Of N-Oxidation onthe Molecular and Crystal Structures and Properties of Isocinchomeronic Acid, Its Metal Complexes and Their Supramolecular Architectures: Experimental, CSD Survey, Solution and Theoretical Approaches. RSC Adv. 2019, 9, 25382-25404.

(15) Hosseini-Hashemi, Z.; Mirzaei, M.; Eshtiagh-Hosseini, H.; Sadeghi, F.; Shamsipur, M.; Ardalani, M.; Black, A. J. Solid and Solution States Studies of Two Mn(II) Complexes Based on NOxidized Pyridine-2,5-Dicarboxylic Acid. J. Coord. Chem. 2018, 71, 4058-4071.

(16) Kamatchi, T. S.; Chitrapriya, N.; Lee, H.; Fronczek, C. F.; Fronczek, F. R.; Natarajan, K. Ruthenium(II)/(III) Complexes of 4Hydroxy-Pyridine-2,6-Dicarboxylic Acid with $\mathrm{PPh}_{3} / \mathrm{AsPh}_{3}$ as CoLigand: Impact Of Oxidation State and Co-Ligands on Anticancer Activity in Vitro. Dalton Trans. 2012, 41, 2066-2077.

(17) Mirzaei, M.; Eshtiagh-Hosseini, H.; Hassanpoor, A.; Szymanska-Buzar, T.; Mague, J. T.; Korabik, M.; Kochel, A. Two New $\mathrm{Cu}^{\mathrm{II}} 1 \mathrm{D}$-Coordination Polymers Containing 1,4-Pyrazine-2,3Dicarboxylic Acid, 2-Aminopyridine, and 5-Bromo-6-Methyl-2-(4Methylpiperazine-1-yl)Pyrimidine-4-Amine: X-Ray Crystal Structure, Spectroscopic and Magnetic Studies. Inorg. Chim. Acta 2012, 391, 232-238.

(18) Mautner, F. A.; Albering, J. H.; Vicente, R.; Andrepont, C.; Gautreaux, J. G.; Gallo, A. A.; Massoud, S. S. Synthesis, Structure and Magnetic Investigations of Polycarboxylato-Copper(II) Complexes. Polyhedron 2013, 54, 158-163.

(19) Balzarini, J.; Stevens, M.; De Clercq, E.; Schols, D.; Pannecouque, C. Pyridine N-Oxide Derivatives: Unusual Anti-HIV Compounds with Multiple Mechanisms of Antiviral Action. J. Antimicrob. Chemother. 2005, 55, 135-138.

(20) Xiong, Y.; Fan, Y. Z.; Yang, R.; Chen, S.; Pan, M.; Jiang, J. J.; $\mathrm{Su}, \mathrm{C}$. Y. Amide and N-Oxide Functionalization of T-Shaped Ligands for Isoreticular Mofs with Giant Enhancements in $\mathrm{CO}_{2}$ Separation. Chem. Commun. 2014, 50, 14631-14634.

(21) Lis, S.; Hnatejko, Z.; Barczynski, P.; Elbanowski, M. Luminescence Studies of Eu(III) Mixed Ligand Complexes. J. Alloys Compd. 2002, 344, 70-74.

(22) Sarma, B.; Nath, N. K.; Bhogala, B. R.; Nangia, A. Synthon Competition and Cooperation in Molecular Salts of Hydroxybenzoic Acids and Aminopyridines. Cryst. Growth Des. 2009, 9, 1546-1557.

(23) Perrin, D. D.; Dempsey, B.; Serjeant, E. P. pKa Prediction for Organic Acids, Bases; Chapman and Hall: London, New York; 1981; Vol. 1.

(24) Aghabozorg, H.; Ghadermazi, M.; Attar Gharamaleki, J. Crystal Structure of a Novel Proton-Transfer Compound: Piperazinium Pyridine-3,5-Dicarboxylate. Anal. Sci.: X-Ray Struct. Anal. Online 2007, 23, $\mathrm{x} 209-\mathrm{x} 210$

(25) Aghabozorg, H.; Ghadermazi, M.; Attar Gharamaleki, J. A Proton-Transfer Compound: 1,10-Phenanthrolinium-2,4,5-Tricarboxy-Benzoate-2,5-Dicarboxy-Benzene-1,4-Dicarboxyl-ate (4/2/1). Acta Crystallogr., Sect. E: Struct. Rep. Online 2006, 62, o3174-o3176.

(26) Sun, H. L.; Wang, X. L.; Jia, L.; Cao, W.; Wang, K. Z.; Du, M. Lanthanide-Pyridyl-2,5-Dicarboxylate N-Oxide Frameworks with Rutile Topology. CrystEngComm 2012, 14, 512-518.

(27) CrysAlis PRO; Oxford Diffraction Ltd.: 2007.

(28) Sheldrick, G. M. ActaCrystallogr. A Short History of SHELX. Acta Crystallogr., Sect. A: Found. Crystallogr. 2008, 64, 112-122.

(29) Frisch, M. J.; Trucks, G. W.; Schlegel, H. B.; Scuseria, G. E.; Robb, M. A.; Cheeseman, J. R.; Scalmani, G.; Barone, V.; Petersson, G. A.; Nakatsuji, H.; Li, X.; Caricato, M.; Marenich, A. V.; Bloino, J.; Janesko, B. G.; Gomperts, R.; Mennucci, B.; Hratchian, H. P.; Ortiz, J. V.; Izmaylov, A. F.; Sonnenberg, J. L.; Williams-Young, D.; Ding, F.; Lipparini, F.; Egidi, F.; Goings, J.; Peng, B.; Petrone, A.; Henderson, T.; Ranasinghe, D.; Zakrzewski, V. G.; Gao, J.; Rega, N.; Zheng, G.; Liang, W.; Hada, M.; Ehara, M.; Toyota, K.; Fukuda, R.; Hasegawa, J.; Ishida, M.; Nakajima, T.; Honda, Y.; Kitao, O.; Nakai, H.; Vreven, T.; Throssell, K.; Montgomery, J. A., Jr.; Peralta, J. E.; Ogliaro, F.; Bearpark, M. J.; Heyd, J. J.; Brothers, E. N.; Kudin, K. N.; Staroverov, V. N.; Keith, T. A.; Kobayashi, R.; Normand, J.; Raghavachari, K.; Rendell, A. P.; Burant, J. C.; Iyengar, S. S.; Tomasi, J.; Cossi, M.; Millam, J. M.; Klene, M.; Adamo, C.; Cammi, R.; Ochterski, J. W.; Martin, R. L.; Morokuma, K.; Farkas, O.; Foresman, J. B.; Fox, D. J. Gaussian 16, rev. A.01; Gaussian, Inc.: Wallingford, CT, 2016.

(30) Bader, R. F. W. A Bond Path: A Universal Indicator of Bonded Interactions. J. Phys. Chem. A 1998, 102, 7314-7323.

(31) Keith, T. A. AIMAll, ver. 13.05.06; TK Gristmill Software: Overland Park, KS, 2013.

(32) Nakamoto, K. Infrared, Raman Spectra of Inorganic, Coordination Compounds, Part B: Applications in Coordination, Organometallic, Bioinorganic Chemistry, 6th ed.; Wiley: New York, 2009.

(33) Mirzaei, M.; Eshtiagh-Hosseini, H.; Bazargan, M.; Mehrzad, F.; Shahbazi, M.; Mague, J. T.; Bauzá, A.; Frontera, A. Two New Copper and Nickel Complexes of Pyridine-2,6-Dicarboxylic Acid N-Oxide and Their Proton Transferred Salts: Solid State and DFT Insights. Inorg. Chim. Acta 2015, 438, 135-145.

(34) Etter, M. C.; Macdonald, J. C. Graph-Set Analysis of HydrogenBond Patterns in Organic Crystals. Acta Crystallogr., Sect. B: Struct. Sci. 1990, 46, 256-262.

(35) Bis, J. A.; Zaworotko, M. J. The 2-AminopyridiniumCarboxylate Supramolecular Heterosynthon: A Robust Motif for Generation of Multiple-Component Crystals. Cryst. Growth Des. 2005, 5, 1169-1179.

(36) Janiak, C. A Critical Account on $\pi-\pi$ Stacking in Metal Complexes with Aromatic Nitrogen-Containing Ligands. Dalton Trans. 2000, 3885-3896.

(37) Mirzaei, M.; Eshtiagh-Hosseini, H.; Karrabi, Z.; Molcanov, K.; Eydizadeh, E.; Mague, J. T.; Bauzá, A.; Frontera, A. Crystal Engineering with Coordination Compounds of $\mathrm{Ni}^{\mathrm{II}}, \mathrm{Co}^{\mathrm{II}}$, And $\mathrm{Cr}^{\mathrm{III}}$ Bearing Dipicolinic Acid Driven by The Nature of The Noncovalent Interactions. CrystEngComm 2014, 16, 5352-5363. 
(38) Huang, T. H.; Yang, H.; Yang, G.; Li, Y.; Huang, L. L. Synthesis, Structures and Properties of $\mathrm{Ag}^{+}$Complexes Containing Polyphosphine Ligands with Extended Ag $\cdots \mathrm{C}, \mathrm{N}-\mathrm{O} \cdots \pi$ and $\mathrm{C}-\mathrm{H} \cdots \pi$ Interactions. J. Mol. Struct. 2016, 1117, 30-36.

(39) Sikorski, A.; Trzybinski, D. Anion-Controlled Networks of Intermolecular Interactions in the Crystal Structure of 9-Aminoacridinium Salts. Tetrahedron 2011, 67, 1479-1484.

(40) Sikorski, A.; Trzybinski, D. The Influence of Benzoate Anion Substituents on the Crystal Packing and Hydrogen-Bonding Network of 9-Aminoacridinium Salts. Tetrahedron 2011, 67, 2839-2843.

(41) García-Raso, A.; Terrón, A.; López-Zafra, A.; García-Viada, A.; Barta, A.; Frontera, A.; Lorenzo, J.; Rodríguez-Calado, S.; VázquezLópez, E. M.; Fiol, J. J. Crystal Structures of $\mathrm{N}^{6}$-Modified-Amino Acid Related Nucleobase Analogs (II): Hybrid Adenine- $\beta$-Alanine and Adenine-GABA Molecules. New J. Chem. 2019, 43, 9680-9688.

(42) Espinosa, E.; Molins, E.; Lecomte, C. Hydrogen Bond Strengths Revealed by Topological Analyses of Experimentally Observed Electron Densities. Chem. Phys. Lett. 1998, 285, 170-173.

(43) Vener, M. V.; Egorova, A. N.; Churakov, A. V.; Tsirelson, V. G. Intermolecular Hydrogen Bond Energies in Crystals Evaluated Using Electron Density Properties: DFT Computations with Periodic Boundary Conditions. J. Comput. Chem. 2012, 33, 2303-2309.

(44) Spackman, M. A.; Jayatilaka, D. Hirshfeld Surface Analysis. CrystEngComm 2009, 11, 19-32.

(45) McKinnon, J. J.; Jayatilaka, D.; Spackman, M. A. Towards Quantitative Analysis of Intermolecular Interactions with Hirshfeld Surfaces. Chem. Commun. 2007, 44, 3814-3816.

(46) Zaręba, J. K.; Białek, M. J.; Janczak, J.; Zoń, J.; Dobosz, A. Extending the Family of Tetrahedral Tectons: Phenyl Embraces in Supramolecular Polymers of Tetraphenylmethane-based Tetraphosphonic Acid Templated by Organic Bases. Cryst. Growth Des. 2014, $14,6143-6153$

(47) Zaręba, J. K. Tetraphenylmethane and Tetraphenylsilane as Building Units of Coordination Polymers and Supramolecular Networks - A Focus On Tetraphosphonates. Inorg. Chem. Commun. 2017, 86, 172-186.

(48) Bulut, A.; Zorlu, Y.; Kirpi, E.; Çetinkaya, A.; Wörle, M.; Beckmann, J.; Yücesan, G. Synthesis of $\mathrm{Cu}$ (II)-Organophosphonate Framework with Predefined Void Spaces. Cryst. Growth Des. 2015, 15, 5665-5669.

(49) Bulut, A.; Wörle, M.; Zorlu, Y.; Kirpi, E.; Kurt, H.; Zubieta, J.; Grabowsky, S.; Beckmann, J.; Yücesan, G. A Potential Cu/VOrganophosphonate Platform for Tailored Void Spaces Via Terpyridine Mold Casting. Acta Crystallogr., Sect. B: Struct. Sci., Cryst. Eng. Mater. 2017, 73, 296-303.

(50) Kumar, M.; Sheikh, H. N.; Fraconetti, A.; Zarȩba, J. K.; Sahoo, S. C.; Frontera, A. 2,5-Furandicarboxylic Acid as a Linker for Lanthanide Coordination Polymers: The Role of Heteroaromatic $\pi-\pi$ Stacking and Hydrogen Bonding. New J. Chem. 2019, 43, 21792195.

(51) Mahmoudi, G.; Zareba, J. K.; Bauzá, A.; Kubicki, M.; Bartyzel, A.; Keramidas, A. D.; Butusov, L.; Miroslaw, B.; Frontera, A. Recurrent Supramolecular Motifs in Discrete Complexes and Coordination Polymers Based on Mercury Halides: Prevalence of Chelate Ring Stacking and Substituent Effects. CrystEngComm 2018, 20, 1065-1076.

(52) Mahmoudi, G.; Zareba, J. K.; Gurbanov, A. V.; Bauzá, A.; Zubkov, F. I.; Kubicki, M.; Stilinovic, V.; Kinzhybalo, V.; Frontera, A. Benzyl Dihydrazone Versus Thiosemicarbazone Schiff Base: Effects on the Supramolecular Arrangement of Cobalt Thiocyanate Complexes and the Generation of $\mathrm{CoN}_{6}$ and $\mathrm{CoN}_{4} \mathrm{~S}_{2}$ Coordination Spheres. Eur. J. Inorg. Chem. 2017, 2017, 4763-4772.

(53) Castiñeiras, A.; García-Santos, I.; González-Pérez, J. M.; Bauzá, A.; Zaręba, J. K.; Niclós-Gutiérrez, J.; Torres, R.; Vílchez, E.; Frontera, A. Multicomponent Supramolecular Assemblies of Melamine and $\alpha$ Hydroxycarboxylic Acids: Understanding the Hydrogen Bonding Patterns and Their Physicochemical Consequences. Cryst. Growth Des. 2018, 18, 6786-6800.
(54) Białek, M. J.; Zaręba, J. K.; Janczak, J.; Zoń, J. Chains, Layers, Channels, and More: Supramolecular Chemistry of Potent Diphosphonic Tectons with Tuned Flexibility. The Generation of Pseudopolymorphs, Polymorphs, and Adducts. Cryst. Growth Des. 2013, 13, 4039-4050. 